\title{
DETERMINANTS OF FOREIGN DIRECT INVESTMENT IN TRANSITION ECONOMIES, WITH SPECIAL REFERENCE TO MACEDONIA: EVIDENCE FROM GRAVITY MODEL ${ }^{1}$
}

Bardhyl Dauti

\section{Abstract}

This paper accounts for the main determinants of Foreign Direct Investment stocks to 5-South East European Countries and the 10-New Member States of the European Union countries by using an augmented Gravity Model, for the purpose of calculating the potential levels of FDI stock in Macedonia. The study takes into account country specific institutional factors that determine foreign investors' decisions from 20 core OECD countries to invest in SEE-5 and EU-NMS-10 countries. From the results of the study we find that gravity factors (market size and distance), institutional related factors (control of corruption, corruption perception index, regulatory quality, transition progress and WTO membership) and other traditional determinants of FDI (schooling, bilateral exports) appear to significantly determine inward FDI stock to the SEE region and new EU member states. The GMM estimates suggest that bilateral FDI stock is subject to persistence effects. The study additionally confirms the relatively strong gravitational character of Macedonia's inward FDI stock.

Key Words: Foreign Direct Investment, SEECs, Panel Econometrics, Gravity Model

JEL: F21

\section{INTRODUCTION}

The aim of this paper is to use panel data on bilateral FDI stocks from individual developed source economies to transitional developing host economies between 1994 and 2010 by focusing on market size, transaction cost and government policies as the determinants of FDI.

This paper investigates the potential level of foreign direct investments (FDI) in Macedonia. In this regard, the paper will consider estimation of bilateral FDI stocks between OECD-20 countries and EU-NMS-10 and SEE-5 using an augmented Gravity Model, based on a panel data set for the period 19942010. Macedonia is selected as a case study, in order to test how the model of the determinants of FDI applies to a semi - developed country. Moreover, the Macedonian government has taken important steps with regard to the promotion of the country to foreign investors, such as significant institutional reforms.
Also, FDI in Macedonia are considered a crucial source of GDP growth, increased employment and exports and a main driving force for enhancement of the transition process in the country. Therefore, considering the importance of FDI for Macedonia's economy, the paper outlines the actual and potential determinants of FDI in Macedonia from source OECD-20 countries.

This study will enrich the empirical literature on FDI determinants, using bilateral data at the country level, by considering also institutional and transition-related factors as crucial in largely determining the size of FDI in transition economies. Moreover, the empirical

Bardhyl Dauti, PhD

Department of Economics, Faculty of Economics

State University of Tetova, Macedonia

E-mail: bardhyl.dauti@unite.edu.mk 
study finds that FDI between the developed OECD-20 countries and the transitional SEE-5 and EU-NMS-10 countries is determined by gravity factors, host country institutional factors, and transition progress.

The paper is organized as follows. The next section presents the review of late empirical literature on FDI determinants in transition economies. Section three presents the methodology and hypothesis. Section four presents the econometric assessment and explanation of the econometric methodologies used for the purposes of estimation. Section five presents the calculation of FDI potentials in Macedonia at stock levels from individual OECD-20 source countries. The last section concludes the study.

\section{LITERATURE REVIEW OF FDI DETERMINANTS IN TRANSITIONECONOMIES}

Numerous studies have dealt with determinants of FDI in transition economies. (Hill et al. 1990; Itaki 1991; Resmini 2000; Bevan and Estrin 2000; Kinoshita and Campos 2004; Dimitri et al. 2005; Botrić and Škuflić 2006; Johnson 2006; Zulfiu 2008; Mateev 2008; Seric 2011; Gorbunova et al. 2012; Estrin and Uvalic 2013; Derado 2013 ).

Hill et al. (1990) discuss strategic, environmental and transaction factors with respect to the decision of entry mode. Strategic factors included the extent of national differences, extent of scale economies and global concentration. Environmental factors include country economic and political risk, demand conditions, and volatility of competition. Transaction cost considerations include the value of firm-specific know-how. The authors conclude that firms undertaking FDI should consider the country risk, since this favors licensing and joint ventures over wholly-owned subsidiaries. The logic behind this rationale lies under marginality rules of the management decision making process. If the establishment cost and the cost of know-how exceed licensing and joint ventures costs, the wholly-owned subsidiaries make no sense.

Itaki (1991) critically examined the Eclectic Paradigm, focusing mainly on the confusion between ownership advantage and location advantage. He argued that the ownership advantage consisted of firm's internal economies of integration, internalized external economies, and minimized transaction cost and market power. Itaki (1991) argued that the Eclectic Paradigm confused the ownership advantage in engineering terms and this advantage is influenced and inspired from location advantages. In this regard, the author suggested that the Eclectic Paradigm theory should differentiate between real and nominal terms.
Agarwal and Ramaswami (1992) examined the Eclectic Paradigm on the choice of entry modes of multinational firms. The results showed that firms used entry modes in high potential markets and they are likely to establish market presence in these markets through direct investments. However, the firm's abilities are constrained by their size and multinational experience.

Bevan and Estrin (2000) analyzed the determinants of FDI flows and country risk, employing a large panel data set for the period 1994-1998. The authors used bilateral data on the flows of FDI between source country i (EU-15) and receipt country j. (Bulgaria, the Czech Republic, Estonia, Hungary, Latvia, Lithuania, Poland, Romania, Slovak Republic, Slovenia and Ukraine). The authors looked at the role of location advantage and internalization advantage as defined in the Eclectic Paradigm. Bevan and Estrin (2000) found that of the location specific advantages, market size is a statistically significant factor for the host countries, owing to greater market opportunities for investors. Contrarily, the authors did not find support under that source for the idea that country size is a significant determinant of FDI inflows. In terms of ownership and internalization advantages, the results suggested distance and unit labor cost are negatively associated to FDI receipts. In this regard, country credit rating variability was also found to be significantly positively correlated with FDI inflows.

Kinoshita and Campos (2004) analyzed the location determinants of FDI into 25 transition economies, utilizing a panel data between 1990 and 1998 . Considering location-specific advantages, within the OLI framework, the authors focused the research on market-seeking factors (to sustain existing markets or exploit new ones), resource-seeking factors (to acquire resources not available in the home country), and efficiency-seeking factors (to enable the firm to gain from the common governance of geographically dispersed activities in the presence of economies of scale and scope). The authors exploited host country characteristics and agglomeration economies as determinants of FDI location, by incorporating the past stock of FDI as a proxy for agglomeration economies. By using the General Method of Moments (GMM) estimation technique the authors found that agglomeration economies are the most significant determinant of FDI in transition economies. However, the poor quality of the bureaucracy in the host country is found to be a deterrent to foreign investment decisions even after controlling for the agglomeration effect. The results of the paper suggested that the more liberalized the country is towards external trade, the more FDI it will attract, confirming the finding of many studies 
that trade and FDI are complementary to each other.

Derado (2013) employing panel data set for the period 1990-2004, analyzed the determinants of inward FDI stock into 12 transition economies originated from five foreign investor countries in the region. Contrary to expectations the author found negative and significant coefficient of GDP per capita in source countries, providing evidence that high income countries reduce their bilateral FDI activity to transition economies. The author also found a significant and positive impact from openness, an EU adherence dummy variable and small scale privatization on FDI for transition economies. Some additional studies of the determinants of Foreign Direct Investments in transition economies are presented in the tables below.

Table 1: Main findings for some of the determinants of FDI, suggested by empirical literature

\begin{tabular}{|c|c|c|c|c|}
\hline Author & Dimitri et al. (2005) & Botrić and Škuflić (2006) & Andreas Johnson (2006) & Zulfiu (2008) \\
\hline Investigation & $\begin{array}{l}\text { Foreign Direct } \\
\text { Investment in South } \\
\text { Eastern Europe: How } \\
\text { (and How Much) Can } \\
\text { Policies Help? }\end{array}$ & $\begin{array}{l}\text { Main Determinants } \\
\text { Foreign Direct } \\
\text { Investment in the } \\
\text { South East European } \\
\text { Countries. }\end{array}$ & $\begin{array}{l}\text { FDI inflows to the } \\
\text { Transition Economies } \\
\text { in Eastern Europe: } \\
\text { Magnitude and } \\
\text { Determinants }\end{array}$ & $\begin{array}{l}\text { Determinants of } \\
\text { Foreign Direct } \\
\text { Investment in Transition } \\
\text { Economies: With } \\
\text { particular Reference } \\
\text { to Macedonia's } \\
\text { Performance }\end{array}$ \\
\hline $\begin{array}{l}\text { Sample and } \\
\text { period }\end{array}$ & $\begin{array}{l}\text { Data: Panel Data, bilat- } \\
\text { eral FDI flows between } \\
15 \text { host and } 24 \text { source } \\
\text { countries. Period: } \\
2000-2002\end{array}$ & $\begin{array}{l}\text { Sample: SEE - } 7 \\
\text { countries. } \\
\text { Period: } 1996 \text { - } 2002\end{array}$ & $\begin{array}{l}25 \text { Transition Economies } \\
\text { of CEE countries and CIS } \\
\text { countries. Period: } 1993 \\
-2003\end{array}$ & $\begin{array}{l}\text { Host country: } \\
\text { Macedonia } \\
\text { Source country: } 29 \\
\text { source countries: } \\
\text { Period: 1997-2003 }\end{array}$ \\
\hline Methodology & $\begin{array}{l}\text { Panel Analysis } \\
\text { GMM (General Method } \\
\text { of Moments) }\end{array}$ & $\begin{array}{l}\text { Panel Analysis: } \\
\text { Methodology. } \\
\text { Generalized Least } \\
\text { Square (GLS) }\end{array}$ & $\begin{array}{l}\text { Panel Analysis } \\
\text { Methodology: } \\
\text { Time invariant fixed ef- } \\
\text { fect, random effect and } \\
\text { pooled OLS }\end{array}$ & $\begin{array}{l}\text { One way RE and FE and } \\
\text { System GMM and differ- } \\
\text { ence GMM }\end{array}$ \\
\hline Findings & $\begin{array}{l}\text { The findings suggest } \\
\text { that high unit labor } \\
\text { costs, a high perfor- } \\
\text { mance tax burden, and } \\
\text { to a lesser extent a high } \\
\text { level of import tariff } \\
\text { discourage FDI, while a } \\
\text { liberal foreign exchange } \\
\text { and trade regime and } \\
\text { advanced reforms in } \\
\text { the infrastructure sector } \\
\text { encourage FDI. }\end{array}$ & $\begin{array}{l}\text { Openness has a signifi- } \\
\text { cant positive effect on } \\
\text { FDI. At the same time } \\
\text { characteristics of the } \\
\text { economies, such as } \\
\text { private sector share or } \\
\text { service sector share, also } \\
\text { proved to be significant } \\
\text { and exerted positive } \\
\text { influence on FDI. Thus, } \\
\text { increasing trade with } \\
\text { other economies posi- } \\
\text { tively influences FDI. }\end{array}$ & $\begin{array}{l}\text { Using panel data into } \\
\text { a CEE sample Johnson } \\
\text { found that the proxies } \\
\text { for host country de- } \\
\text { mand has a significant } \\
\text { positive effect on FDI. } \\
\text { The result suggested } \\
\text { that market seeking } \\
\text { (absolute GDP, GDP per } \\
\text { capita) is an important } \\
\text { motive for investment in } \\
\text { the CEE economies }\end{array}$ & $\begin{array}{l}\text { Using One way RE the } \\
\text { author found a positive } \\
\text { and statistically signifi- } \\
\text { cant coefficient for host } \\
\text { country GDP and open- } \\
\text { ness and negative and } \\
\text { a statistically significant } \\
\text { coefficient for distance } \\
\text { Using one step and two } \\
\text { step results from system } \\
\text { and difference GMM the } \\
\text { author found evidence } \\
\text { that FDI stock is subject } \\
\text { to persistence effects }\end{array}$ \\
\hline
\end{tabular}

Notes: Summary papers with empirical studies. 
Table 2: Main findings for some of the determinants of FDI, suggested by empirical literature

\begin{tabular}{|c|c|c|c|c|}
\hline Author & Miroslav Mateev (2008) & Adan Seric (2011) & Gorbunova et al. (2012) & Estrin and Uvalic (2013) \\
\hline Investigation & $\begin{array}{l}\text { Determinants of Foreign } \\
\text { Direct Investment } \\
\text { in Central and } \\
\text { Southeastern Europe: } \\
\text { New Empirical Test }\end{array}$ & $\begin{array}{l}\text { Determinants of FDI } \\
\text { location in Central and } \\
\text { Eastern Europe. }\end{array}$ & $\begin{array}{l}\text { New Evidence of FDI } \\
\text { Determinants: An } \\
\text { Appraisal over the tran- } \\
\text { sition period }\end{array}$ & $\begin{array}{l}\text { Foreign direct invest- } \\
\text { ment into transition } \\
\text { economies. Are the } \\
\text { Balkans different? }\end{array}$ \\
\hline $\begin{array}{l}\text { Sample and } \\
\text { period }\end{array}$ & $\begin{array}{l}\text { Host countries of FDI } \\
\text { are } 8 \text { transition econo- } \\
\text { mies: Hungary, Poland, } \\
\text { the Check Republic, } \\
\text { Slovakia, Slovenia, } \\
\text { Bulgaria, Romania, and } \\
\text { Croatia } \\
\text { Source countries of FDI: } \\
\text { EU-12 countries } \\
\text { Period: } 2001-2006\end{array}$ & $\begin{array}{l}\text { All CEE countries } \\
\text { Using yearly data from } \\
1995 \text { to } 2000\end{array}$ & $\begin{array}{l}26 \text { former socialist } \\
\text { countries } \\
\text { Period: } 1994-2002\end{array}$ & $\begin{array}{l}\text { Host: } 17 \text { transition } \\
\text { countries } \\
\text { Source: More than } \\
70 \text { countries. Focus } \\
\text { group: SEE-7: } \\
\text { Albania, Bosnia and } \\
\text { Herzegovina, Bulgaria, } \\
\text { Croatia, Macedonia, } \\
\text { Montenegro, Romania } \\
\text { and Serbia } \\
\text { Period: } 1990-2011\end{array}$ \\
\hline Methodology & $\begin{array}{l}\text { cross-section panel } \\
\text { data analysis: LSDV with } \\
\text { source country dummy }\end{array}$ & $\begin{array}{l}\text { Fixed Effect and } \\
\text { Dynamic Panel } \\
\text { Estimation: two step } \\
\text { least square regression }\end{array}$ & $\begin{array}{l}\text { Feasible GLS and Prais - } \\
\text { Winston transformation }\end{array}$ & OLS \\
\hline Findings & $\begin{array}{l}\text { It was found that gravity } \\
\text { factors (GDP, population, } \\
\text { distance and cultural } \\
\text { proximity) and cost and } \\
\text { transition specific fac- } \\
\text { tors (wages, corruption } \\
\text { and risk credit rating) } \\
\text { are statistically signifi- } \\
\text { cant with the estimated } \\
\text { sign as expected. }\end{array}$ & $\begin{array}{l}\text { FDI into transition } \\
\text { countries } \\
\text { is driven mainly by } \\
\text { market potentials, low } \\
\text { labor cost and produc- } \\
\text { tivity, low labor cost, } \\
\text { and abundant natural } \\
\text { resources. FDI in transi- } \\
\text { tion economies might } \\
\text { be market and efficiency } \\
\text { seeking. }\end{array}$ & $\begin{array}{l}\text { FDI are determined by } \\
\text { market and institutional } \\
\text { factors. Among market } \\
\text { variables, relatively high- } \\
\text { er labor costs unexpect- } \\
\text { edly do not represent an } \\
\text { problem for foreign } \\
\text { investment. The vari- } \\
\text { ables proxying market } \\
\text { stabilizing institutions } \\
\text { play a more important } \\
\text { role than those proxy- } \\
\text { ing market creating } \\
\text { institutions. }\end{array}$ & $\begin{array}{l}\text { Using augmented } \\
\text { gravity model with } \\
\text { institutional variable } \\
\text { and dummy variable } \\
\text { capturing EU member- } \\
\text { ship, the authors found } \\
\text { that, Western Balkans } \\
\text { countries receive less } \\
\text { FDI than other transition } \\
\text { economies. }\end{array}$ \\
\hline
\end{tabular}

Notes: Summary papers with empirical studies.

\section{METHODOLOGY, EMPIRICAL APPROACH AND DATA}

In line with the theoretical framework of FDI determinants, we consider the role of geography in explaining the FDI pattern among SEE and CEE countries and other policy factors either resisting or promoting FDI by using the conceptual framework of the gravity model. The reduced form of the model including related selected variables is given below:
Where fdi $_{i j, t}$ is a bilateral FDI stock from source country $i$ to host country $j$ at time $t$, in millions of US dollars. gdp $\mathrm{p}_{\mathrm{ij}, \mathrm{t}-1}$ represents market size variables denoting the gross domestic product, in millions of US dollar in source and host country, respectively. Both variables are lagged by 1 time period, in order to control for endogeneity problems between FDI and GDP. We use the absolute difference of GDP per capita variable between source country and host country at time

$$
\begin{aligned}
\ln f d i_{i j, t}=a_{i j} & +u_{t}+b_{0} \operatorname{lng} d p_{i, t-1}+b_{1} \operatorname{lng} d p_{j, t-1}+b_{2} \ln \left|g d p c_{i, t-1}-g d p c_{j, t-1}\right| \\
& +b_{3} \ln x_{j t}+b_{4} \ln y_{j t}+b_{5} \ln y_{j t} \times d+d+\varphi+\delta+\theta+\varepsilon_{i j, t}
\end{aligned}
$$


$\mathrm{t}\left|g d p c_{i, t-1^{-}} g d p c_{j, t-1}\right|$ as measures of factor endowment differentials between countries. The absolute difference of GDP per capita, between source and host country, will allow us to control for serial correlation between GDP and GDP per capita variable (Greene 2013). The country-pair specific effects, $a_{i j}$ captures all the time invariant factors, such as distance, common land border, common language etc, while $u_{t}$ is a time dummy, $\varphi$ is host country dummy and $\sigma$ is source country dummy and $\theta$ is pair country dummy, $\mathrm{x}_{\mathrm{jt}}$ represent the vector of host country explanatory variables. $y_{j t}$ stands for host country institutional-related variables and $\mathrm{y}_{\mathrm{j}^{+}} \mathrm{d}$ stands for host country institutional-related variables interacted with SEE dummy variable. The interaction terms, $\mathrm{y}_{\mathrm{j} \mathrm{t}^{*} \mathrm{~d}}$ is included in the model to estimate the institutional determinants of inward FDI stock in SEE-5 countries, d denotes the constitutive term proxying SEE dummy variable. The EU-NMS-10 country group is taken as control group. $\varepsilon_{\mathrm{ijt}}$ is the standard error term.

\subsection{Empirical model}

Following the work of Bevan and Estrin (2004), Johnson (2006) and Mateev (2008) applied to the OLI framework, we employ the gravity model for explaining FDI patterns, among countries that have invested in the SEE-5 countries and EU-NMS-10. For estimation purposes, the extended gravity equation for FDI stocks in SEE and EU-NMS-10 countries is specified in the equation $(2)^{2}$ :

$$
\begin{aligned}
\operatorname{lnfdi}_{i j, t}=a_{i j} & +u_{t}+b_{0} \operatorname{lng}_{i, t-1}+b_{1} \operatorname{lng}_{i n} p_{j, t-1}+b_{2} \operatorname{lnd}_{i j} \\
& +b_{3} \ln \left|g d p c_{i, t-1}-g d p c_{j, t-1}\right|+b_{4} \text { smctry }_{i j} \\
& +b_{5} \operatorname{wto}_{j t}+b_{6} b f d i_{j t}+b_{7} \operatorname{lnbex}_{j i, t}+b_{8} \operatorname{lnsch}_{j t}+b_{9} \operatorname{lntp}_{j t}+b_{10} \operatorname{lncpi}_{j t} \\
& +b_{11} \operatorname{lncc}_{j t}+b_{12} \operatorname{lnrq}_{j t}+b_{13} \operatorname{lng}_{j \mathrm{ov}}+b_{14} \operatorname{lnrl}_{j t}+b_{15} \operatorname{lnpr}_{j t}+b_{16} \operatorname{lnva}_{j t} \\
& +b_{17} \operatorname{lntp}_{j t} \times d+b_{18} \operatorname{lncpi}_{j t} \times d+b_{19} \operatorname{lncc}_{j t} \times d+b_{20} \operatorname{lnrq}_{j t} \times d \\
& +b_{21} \operatorname{lngov}_{j t} \times d+b_{22} \operatorname{lnrl}_{j t} \times d+b_{23} \operatorname{lnpr}_{j t} \times d+b_{24} \operatorname{lnva}_{j t} \times d+d+\varphi \\
& +\delta+\theta+\varepsilon_{i j, t}
\end{aligned}
$$

Where i denotes a source country of FDI (OECD20), j denotes individual SEE-5 and EU-NMS-10 receipt countries, $t$ denotes the years from 1994 to 2010. The empirical model assumes that bilateral FDI in SEE and EU-NMS countries is a function of GDP, GDP per capita, distance, language, cultural and border similarities, world trade organization membership of the host economy, bilateral FDI agreement, trade openness, bilateral exports, schooling, transition progress, corruption perception index and world governance indicators like control of corruption, regulatory quality, government effectiveness, rule of law, political risk and voice and accountability. The dependent variable fdi $\mathrm{i}_{\mathrm{ijt}}$ is defined as the bilateral stock of FDI from source country $i$ to host country $j$ at time t. The source of this data is the OECD. The FDI stock variable contains a large number of zero observations and negative values ${ }^{3}$.

\subsection{Data description and hypothesis}

Along the lines of previous research, the dependent variable fdi $_{i j t}$ is defined as the bilateral stock of FDI from source country $i$ to host country $j$ at time $t$. The source of this data is the OECD. The FDI stocks are measured at current prices and current exchange rate in millions of US dollars.

Using a gravity framework, the expected economic factors that determine the size of FDI bilateral are: the market size factors represented by GDP and absolute difference of GDP per capita between source and host countries, and the transaction cost factor representing the distance. In the empirical model we include the variables of $g_{d p}$ and gdp ${ }_{\mathrm{jt}}$ to consider the market size of host and source country. The empirical literature suggests a positive relationship between market size factors and the size of FDI (Bevan and Estrin 2004; Johnson 2006; Mateev 2008). The explanation is that the bigger the host country GDP the larger the FDI, since larger economies become more attractive for foreign capital. The larger the origin country of FDI the more FDI should emerge from this country; and the larger the market size of a host country the more FDI it should receive. Thus, for both variables we expect positively signed coefficients. The source of this data is UNCTAD.

In the empirical model we also include the variable of the absolute difference of GDP per capita between countries to capture the market size differentials between countries, as well as factor endowments 
differentials between countries. In line with the Linder hypothesis (1961), it can also be taken to account for the differences in consumer tastes between countries. Moreover, considering the Linder's preference-based theory (1953), the effects of country characteristics, denoted by GDP per capita on FDI, do not accord well by including the respective levels of GDP per capita for both countries, but, rather by considering the absolute differences of GDP per capita between countries (Frankel et al. 1995) ${ }^{4}$. Based on the concept of cost comparative differences and combined tastes between countries, it is expected that high income OECD countries will focus their investments more towards relatively low income EU-NMS-10 and SEE-5 countries. Hence, there is an expected positive impact from the absolute difference of GDP per capita variable on FDI. However, the empirical literature suggests both positive and negative relationships between factor cost differentials and FDI (Globerman and Shapiro 2002). The positive (negative) sign of this variable may also be due to the fact that differences in wage levels are compensated (or not compensated) by productivity (Bergstrand 1989).The source of the data for this variable is UNCTAD.

The transaction cost variable in this study is represented by the distance between source and host country. The variable of distance $\operatorname{lnd}_{\mathrm{ijt}}$ represents a gravity factor. Distance between source and host country is expected to have a negative effect on the size of FDI, due to costly adoptions of goods to local preferences (Johnson 2006) and high transportation costs (Bevan and Estrin 2000; Resmini, 2000). The variable of distance is measured by the actual route distance between the economic centers (generally, capital cities) of the source and host countries in kilometers. This variable is used in the model to proxy for the transaction, transportation cost and physical cost of foreign investments ${ }^{5}$. According to Resmini (2000), greater distance presents weaker trade ties between the FDI source country and the host country, thus providing for lower FDI stock levels. Typically, empirical studies proxy trade costs with bilateral distance.

However, a number of additional variables are also customarily used. In this regard, the model also includes additional gravity factors through dummy variables, like smctry $y_{i j}$ which is a dummy variable that takes value one when two countries share a border, a language or were the same country in the past, correspondingly. In all cases, the coefficient is expected to be positive. This variable is used to capture information costs and search costs, which are probably lower for foreign investors whose business practices, competitiveness and delivery reliability are well known to one another. Firms in adjacent countries, or countries with common relevant cultural features, are likely to know more about each other and to understand each other's business practices better than firms operating in less similar environments. The source of the data for smctry $_{\mathrm{ij}}$ is CEPII.

The variable $\operatorname{lnbex}_{\mathrm{jit}-1}$ is considered in the model to account for bilateral exports from host country $j$ to source country $i$. This variable is lagged by one time period to allow the bilateral exports the grace period before it starts impacting host country's inward stock of FDI. It is expected that host country bilateral exports encourage more FDI. Hence, export-oriented economies may be more successful in encouraging FDI. Therefore it is expected that a positive relationship exists between lagged bilateral exports and FDI. The source of the data for $\mathrm{lbex}_{\mathrm{jit}}$ is the OECD.

The variable $\operatorname{lnsch} \mathrm{h}_{\mathrm{jt}}$ accounting for years of schooling of the host country population is measured by tertiary school enrolment as a per cent of gross school enrolment. This variable will account for efficiencyseeking motives of FDI, capturing the human capital developments in the host country (Borensztein et al. 1998). According to the research literature, there is a strong positive relationship between FDI and the level of educationalattainment in the domestic economy. In line with Borensztein et al. (1998) this variable is expected to present a positive relation to FDI: the more educated the workforce, the greater the incentive for investment, since a better educated workforce yields higher returns. Data is obtained from the World Bank database on education.

We augment the gravity model by considering additional explanatory variables that are expected to be significant FDI determinants. Therefore, considering the empirical work of Holland and Pain (1988), Mora et al. (2001), Kinoshita and Campos (2004), Bevan and Estrin (2004), we find that the importance of institutional development factors is significantly important for the investment decisions of foreign investors. Moreover, the quality of institutions is crucially important for less developed SEE countries. In the study we proxy for the quality of institutions in the host country through the World Bank's Worldwide Governance Indicators (WGI), which include six relevant measures, on per centile rank values, like control of corruption, regulatory quality, rule of law, government effectiveness, political risk and voice and accountability. These measurements are used in the study in order to account for institutional quality and advancement issues (economic and political institutions).

The index of control of corruption lncc $c_{j t}$ captures perceptions of the extent to which public power is exercised for private gain, including both petty and grand forms of corruption, as well as "capture" of the 
state by elites and private interests. It is expected that control of corruption will be negatively associated with bilateral FDI. The index of regulatory quality In$\mathrm{rq}_{\mathrm{jt}}$ measures perception of the ability of the government to formulate and implement sound policies and regulations that permit and promote private sector development. It is expected that regulatory quality index will be positively related to bilateral FDI. The index of rule of law $\operatorname{lnrl}_{\mathrm{jt}}$ measures the perceptions of the extent to which economic agents have confidence in and abide by the rules of society, and in particular the quality of contract enforcement, property rights, the police and the courts, as well as the likelihood of crime and violence. It is expected that economic agents' confidence in the host country's institutional system, represented by quality of contract enforcement and property rights, will be positively related to bilateral FDI. The index of voice and accountability lnva $a_{j t}$ captures perception of the extent to which a country's citizens are able to participate in selecting their government, as well as freedom of expression, freedom of association, and a free media. The political stability index $\operatorname{lnps} s_{j t}$ captures the perception of the likelihood that the government will be destabilized or overthrown by unconstitutional or violent means, including politically-motivated violence and terrorism. The government effectiveness index lngov j $_{\mathrm{jt}}$ captures perception of the quality of public services, the quality of the civil service and the degree of its independence from political pressures, the quality of policy formulation and implementation and the credibility of the government's commitment to such policies. In general, it is expected that bilateral FDI from source to host country will increase as the overall institutional conditions in the SEE- 5 and EU-NMS-10 host countries improve. Therefore, a positive relationship between FDI and host country governance indicators is expected.

The variable $\operatorname{lntp}_{j \mathrm{t}}$ is included in the model to capture the transition progress of host country institutions. Following Mrak and Rojec (2013), this variable is constructed by the sum of seven EBRD transition specific indexes, i.e. the indexes denoting large scale privatization, enterprise restructuring, competition policy, banking reforms and interest rates liberalization, securities markets and non-bank financial institutions, and infrastructure reform. Transition progress is included in the model as policy determinants of FDI to reflect the main transition characteristics of SEE- 5 and EU-NMS- 10 countries. It is expected that the transition progress will be positively associated with bilateral FDI stocks. The source of the data for this variable is the European Bank of Reconstruction and Development (EBRD).

Additionally, the Transparency International
Corruption Perception Index (CPI) is included in the study to address the level of perceived corruption and to capture the investment climate in the host countries. The variable $\operatorname{lncpi}_{\mathrm{jt}}$ is measured by perceived corruption on a continuous scale from 1 to 10 . In the model, we account for the effects of corruption as an institutionally-related determinant. The data is collected from Transparency International's website. The variable is expected to have a positive relationship with FDI stocks, since a higher value of the corruption index indicates a less corrupt business environment in the host country.

However, in the study there are also other institutional dummy variables included. The dummy variables, such as wto $\mathrm{j}_{\mathrm{jt}}$, bfdia $_{\mathrm{ijt}}$ are included in the model in line with the business network theory of FDI flows to denote institutional factors affecting FDI stocks into SEE countries. In this regard, wto ${ }_{j t}$ is included in the model to denote the membership of the receipt country of FDI into the World Trade Organization (WTO). The source of this data is the WTO database. The variable bfdia $a_{i j t}$ is included in the model to denote bilateral investment treaties between country $i$ and $j$ at time $t$. The source of the data for bilateral investment treaties is UNCTAD.

Finally, to address the question of whether the main institutional determinants of FDI are different across the two group of countries (SEE countries versus EU-NMS), in the estimated model we introduce interaction variables between host country institutional variables and SEE dummy variable $d$. These variables are included in order to differentiate between the overall potential for FDI between the SEE- 5 and EUNMS-10 countries. It is expected that inward stocks of FDI may, to a certain extent, be independent of the above country-specific determinants and will be related to the geographic region of SEE that has been plagued by political instability and war for an important part of the time period under consideration. Therefore, the SEE- 5 countries may be considered less attractive locations for FDI.

\section{ECONOMETRICISSUES}

We use different estimation methodologies to estimate the determinants of bilateral FDI stocks from OECD-20 to SEE- 5 and EU-NMS- 10 countries. In this regard, in the study we consider both static panel models and dynamic panel models. Additionally, other estimation techniques are considered in the study, in order to deal with the problem of zero observations in the dependent variable.

The problem with estimating FDI stocks using a 
gravity equation is the multilateral resistance terms (MRTs). To proxy MRTs, following Rose and van Wincop (2001); Feenstra (2004); Baldwin and Taglioni (2006) we use country fixed effects for host countries and source countries, time fixed effects and country-pair fixed effects. Moreover, the LSDV models with time, country and pair dummies are employed to control for common external shocks and unobserved countryfixed effects. An advantage of LSDV estimates is that by adding the dummy for each country we estimate the pure effect of each individual explanatory variable, accounting also for unobserved heterogeneity (Greene 2013). This methodology also identifies individual-country specific and time effects.

However, due to the presence of zero FDI stocks in the FDI data matrix, we also present the results from Poisson Pseudo Maximum Likelihood Estimation technique (PPMLE) and the Random Effects Tobit (RET) estimation technique (Peracchi and Vivano 2004; Santos and Silva 2006). These estimation methodologies are presented in the study, in order to deal with the problem of negative observations in the bilateral FDI stock matrix. This problem can arise due to reporting statistical problems and measurement errors (Razin 2001). In this regard, to solve the problem of negative observations in the dependent variable we transform the dependent variable by replacing the negative values of the bilateral FDI stock data with zero values. By this transformation we take care of negative values and the coefficients from an OLS regression can still be interpreted as elasticity's for large values of the dependent variable (Guerin 2006). The advantages of using PPMLE is that they deal with the problem of zero FDI stocks, provide unbiased and consistent estimates in the presence of heteroscedasticity, all observations are weighted equally and the mean is always positive (Henderson and Millimet 2008; Westerlund and Wilhelmsson 2009; Silva and Tenreyro 2008).

It has been frequently argued that the static panel data approach may lead to biased parameter estimates as it does not take into account the potential endogeneity of explanatory variables. Moreover, the standard static panel model does not correct the biases due to the presence of the lagged dependent variable. Therefore, the use of pooled ordinary least squares (OLS), fixed effects accounting for country and time specific effects or random effects with generalized least squares would be inappropriate, since endogeneity would bias the results. To check for the robustness of our results obtained using the static panel data techniques, we run dynamic panel data regression using Arrellano-Bover/Blundell/Bond estimation procedure (Arrellano and Bover 1995; Blundell and Bond 1998).
One of the advantages of the GMM is that it utilizes a bigger subset of instruments. ${ }^{6}$ However, the drawback of the GMM estimation technique is over fitting the endogenous variables by increasing the number of instruments, thus leading to biased and inconsistent estimates (Roodman 2008). The "system GMM" estimation technique is more suitable for the panel data models with a large number of individuals and a small number of time periods (small T, large N panels), with explanatory variables that are not strictly exogenous (Roodman 2008).

\subsection{Results}

In this section we present the empirical results. We discuss the economic interpretation of the models summarized in Tables 3, 4 and 5 . All of the abovementioned methodologies are presented for estimating the determinants of bilateral FDI. However, every method has its advantages and disadvantages. For this reason, as has become a common practice in empirical literature, we report the results of all of the above mentioned estimation methods for the same database.

\subsubsection{Discussion of results from LSDV models}

To consider whether the institutional determinants of FDI are different across two groups of host countries of (SEE-5 and EU-NMS-10 countries), the results with the interactions of the SEE- 5 dummy variable with host country institutional factors are presented in columns 1-5. Additionally, as a benchmark category of these estimates, we also present the results without interaction terms (column 6). In this case we consider the whole sample of host SEE- 5 and EU-NMS- 10 countries as one group of host countries of FDI. Column 1 shows the results with time dummies. Columns 2 and 3 show the results for time invariant host country and source country fixed effects and for time varying host country and source country fixed effects, respectively. Finally, columns 4 and 5 present a specification where pair effects are also added. Considering these estimates, as Bevan and Estrin (2004) find, the positive and significant coefficients of host and source country GDP and the negative and significant coefficient for distance indicates that FDI is determined by gravity factors, as expected. This means that our results are consistent with a transaction cost analysis of FDI in which FDI stocks are attracted between relatively large economies, but the gains from overseas production diminish with distance from the source country. 
Table 3: Static panel estimates of the determinants of bilateral FDI stock

\begin{tabular}{|c|c|c|c|c|c|c|}
\hline VARIABLES & $\begin{array}{c}\text { (1) } \\
\text { Robust } \\
\text { LSDV }\end{array}$ & $\begin{array}{c}\text { (2) } \\
\text { Robust } \\
\text { LSDV }\end{array}$ & $\begin{array}{c}\text { (3) } \\
\text { Robust } \\
\text { LSDV }\end{array}$ & $\begin{array}{c}\text { (4) } \\
\text { Robust } \\
\text { LSDV }\end{array}$ & $\begin{array}{c}\text { (5) } \\
\text { Robust } \\
\text { LSDV }\end{array}$ & $\begin{array}{c}\text { (6) } \\
\text { Robust } \\
\text { LSDV }\end{array}$ \\
\hline Log of GDP in source c. (-1) & $\begin{array}{c}0.551^{* * *} \\
{[8.38]}\end{array}$ & $\begin{array}{l}-0.406 \\
{[-0.80]}\end{array}$ & $\begin{array}{l}0.009 \\
{[0.02]}\end{array}$ & $\begin{array}{c}0.913^{* *} \\
{[2.51]}\end{array}$ & $\begin{array}{c}0.913^{* *} \\
{[2.51]}\end{array}$ & $\begin{array}{c}0.880^{* *} \\
{[2.37]}\end{array}$ \\
\hline Log of GDP in host. c. (-1) & $\begin{array}{c}0.764^{* * *} \\
{[10.98]}\end{array}$ & $\begin{array}{c}0.573^{* *} \\
{[2.19]}\end{array}$ & $\begin{array}{l}0.896^{*} \\
{[1.89]}\end{array}$ & $\begin{array}{c}0.668^{* *} \\
{[2.16]}\end{array}$ & $\begin{array}{c}0.668^{* *} \\
{[2.16]}\end{array}$ & $\begin{array}{c}1.300^{* * * *} \\
{[4.68]}\end{array}$ \\
\hline Log of diff. in GDPc (-1) & $\begin{array}{c}1.049 * * * \\
{[12.18]}\end{array}$ & $\begin{array}{c}0.727^{* *} \\
{[2.23]}\end{array}$ & $\begin{array}{c}0.732^{* *} \\
{[2.13]}\end{array}$ & $\begin{array}{c}-0.370^{* * * *} \\
{[-2.60]}\end{array}$ & $\begin{array}{c}-0.370^{* * *} \\
{[-2.60]}\end{array}$ & $\begin{array}{c}-0.294^{* *} \\
{[-2.04]}\end{array}$ \\
\hline Log of distance & $\begin{array}{c}-1.395^{* * *} \\
{[-12.03]}\end{array}$ & $\begin{array}{c}-2.802^{* * *} \\
{[-17.71]}\end{array}$ & $\begin{array}{c}-2.825^{* * *} \\
{[-17.80]}\end{array}$ & $\begin{array}{c}-2.629 * * * \\
{[-3.63]}\end{array}$ & $\begin{array}{c}-1.122^{* * *} \\
{[-2.61]}\end{array}$ & $\begin{array}{c}-1.855^{* * *} \\
{[-4.89]}\end{array}$ \\
\hline Same country & $\begin{array}{c}0.633^{* * *} \\
{[4.94]}\end{array}$ & $\begin{array}{c}-1.172^{* * * *} \\
{[-5.29]}\end{array}$ & $\begin{array}{c}-1.174^{* * * *} \\
{[-5.31]}\end{array}$ & $\begin{array}{c}29.522^{* * * *} \\
{[6.78]}\end{array}$ & $\begin{array}{c}5.272^{* * *} \\
{[2.61]}\end{array}$ & $\begin{array}{l}-2.091 \\
{[-1.28]}\end{array}$ \\
\hline WTO membership & $\begin{array}{c}0.411^{* *} \\
{[2.30]}\end{array}$ & $\begin{array}{l}0.101 \\
{[0.62]}\end{array}$ & $\begin{array}{l}0.103 \\
{[0.51]}\end{array}$ & $\begin{array}{l}0.086 \\
{[0.55]}\end{array}$ & $\begin{array}{l}0.086 \\
{[0.55]}\end{array}$ & $\begin{array}{l}0.155 \\
{[1.00]}\end{array}$ \\
\hline Bilateral FDI agreement & $\begin{array}{l}0.280 \\
{[1.36]}\end{array}$ & $\begin{array}{c}0.334^{*} \\
{[1.71]}\end{array}$ & $\begin{array}{l}0.306 \\
{[1.53]}\end{array}$ & $\begin{array}{l}0.063 \\
{[0.38]}\end{array}$ & $\begin{array}{l}0.063 \\
{[0.38]}\end{array}$ & $\begin{array}{l}-0.009 \\
{[-0.05]}\end{array}$ \\
\hline Log of bilateral exports $(-1)$ & $\begin{array}{c}0.386^{* * *} \\
{[7.21]}\end{array}$ & $\begin{array}{c}0.273^{* * *} \\
{[5.51]}\end{array}$ & $\begin{array}{c}0.263^{* * * *} \\
{[5.26]}\end{array}$ & $\begin{array}{c}0.137^{* *} \\
{[2.10]}\end{array}$ & $\begin{array}{c}0.137^{* *} \\
{[2.10]}\end{array}$ & $\begin{array}{c}0.147^{* *} \\
{[2.13]}\end{array}$ \\
\hline Log of Schooling & $\begin{array}{l}-0.205 \\
{[-0.99]}\end{array}$ & $\begin{array}{c}0.956^{* * *} \\
{[4.55]}\end{array}$ & $\begin{array}{l}0.343 \\
{[1.14]}\end{array}$ & $\begin{array}{l}0.313 \\
{[1.31]}\end{array}$ & $\begin{array}{l}0.313 \\
{[1.31]}\end{array}$ & $\begin{array}{l}0.226 \\
{[0.88]}\end{array}$ \\
\hline Log of Transition progress & $\begin{array}{c}5.641^{* * *} \\
{[4.31]}\end{array}$ & $\begin{array}{c}5.198^{* * *} \\
{[4.30]}\end{array}$ & $\begin{array}{c}0.755 \\
{[0.40]}\end{array}$ & $\begin{array}{c}3.395^{* *} \\
{[2.39]}\end{array}$ & $\begin{array}{c}3.395^{* *} \\
{[2.39]}\end{array}$ & $\begin{array}{l}0.811 \\
{[0.53]}\end{array}$ \\
\hline Log of Corruption perc. index & $\begin{array}{l}-0.075 \\
{[-0.17]}\end{array}$ & $\begin{array}{c}-0.902^{* *} \\
{[-2.03]}\end{array}$ & $\begin{array}{c}-0.961^{* *} \\
{[-2.09]}\end{array}$ & $\begin{array}{c}-1.054^{* * *} \\
{[-2.91]}\end{array}$ & $\begin{array}{c}-1.054^{* * *} \\
{[-2.91]}\end{array}$ & $\begin{array}{l}-0.402 \\
{[-1.27]}\end{array}$ \\
\hline Log of Control of corruption & $\begin{array}{l}1.053^{*} \\
{[1.78]}\end{array}$ & $\begin{array}{l}-0.147 \\
{[-0.29]}\end{array}$ & $\begin{array}{l}0.187 \\
{[0.34]}\end{array}$ & $\begin{array}{l}-0.203 \\
{[-0.47]}\end{array}$ & $\begin{array}{l}-0.203 \\
{[-0.47]}\end{array}$ & $\begin{array}{l}0.604^{*} \\
{[1.70]}\end{array}$ \\
\hline Log of Regulatory quality & $\begin{array}{l}0.250 \\
{[0.33]}\end{array}$ & $\begin{array}{l}0.888 \\
{[1.30]}\end{array}$ & $\begin{array}{l}1.309^{*} \\
{[1.71]}\end{array}$ & $\begin{array}{c}1.331^{* *} \\
{[2.33]}\end{array}$ & $\begin{array}{c}1.331^{* *} \\
{[2.33]}\end{array}$ & $\begin{array}{l}0.790^{*} \\
{[1.72]}\end{array}$ \\
\hline Log of Government effectiveness & $\begin{array}{c}-1.538^{* * *} \\
{[-3.24]}\end{array}$ & $\begin{array}{l}-0.057 \\
{[-0.10]}\end{array}$ & $\begin{array}{l}0.677 \\
{[1.02]}\end{array}$ & $\begin{array}{c}1.206^{* *} \\
{[2.48]}\end{array}$ & $\begin{array}{c}1.206^{* *} \\
{[2.48]}\end{array}$ & $\begin{array}{l}0.432 \\
{[1.05]}\end{array}$ \\
\hline Log of Political risk & $\begin{array}{l}-0.346 \\
{[-1.12]}\end{array}$ & $\begin{array}{l}-0.289 \\
{[-0.91]}\end{array}$ & $\begin{array}{l}-0.262 \\
{[-0.73]}\end{array}$ & $\begin{array}{l}-0.229 \\
{[-1.02]}\end{array}$ & $\begin{array}{l}-0.229 \\
{[-1.02]}\end{array}$ & $\begin{array}{l}-0.206 \\
{[-0.95]}\end{array}$ \\
\hline Log of Voice and accountability. & $\begin{array}{l}0.367 \\
{[0.38]}\end{array}$ & $\begin{array}{l}-0.532 \\
{[-0.57]}\end{array}$ & $\begin{array}{l}-0.011 \\
{[-0.01]}\end{array}$ & $\begin{array}{l}1.049 \\
{[1.53]}\end{array}$ & $\begin{array}{l}1.049 \\
{[1.53]}\end{array}$ & $\begin{array}{l}-0.765 \\
{[-1.29]}\end{array}$ \\
\hline Log of Rule of law & $\begin{array}{c}-0.847^{* *} \\
{[-2.09]}\end{array}$ & $\begin{array}{l}0.638 \\
{[1.17]}\end{array}$ & $\begin{array}{l}0.136 \\
{[0.24]}\end{array}$ & $\begin{array}{l}-0.099 \\
{[-0.25]}\end{array}$ & $\begin{array}{l}-0.099 \\
{[-0.25]}\end{array}$ & $\begin{array}{l}-0.692 \\
{[-1.57]}\end{array}$ \\
\hline Log of Corruption perc. index ${ }^{*}$ & $\begin{array}{c}3.305^{* * *} \\
{[2.92]}\end{array}$ & $\begin{array}{l}1.256 \\
{[1.13]}\end{array}$ & $\begin{array}{l}1.284 \\
{[1.15]}\end{array}$ & $\begin{array}{l}1.438^{*} \\
{[1.85]}\end{array}$ & $\begin{array}{l}1.438^{*} \\
{[1.85]}\end{array}$ & \\
\hline Log of Transition progress ${ }^{*} d$ & $\begin{array}{c}-8.480^{* * * *} \\
{[-4.12]}\end{array}$ & $\begin{array}{c}-5.212^{* *} \\
{[-2.33]}\end{array}$ & $\begin{array}{c}-3.666^{*} \\
{[-1.68]}\end{array}$ & $\begin{array}{c}-4.623^{* * * *} \\
{[-2.93]}\end{array}$ & $\begin{array}{c}-4.623^{* * * *} \\
{[-2.93]}\end{array}$ & \\
\hline Log of Control of corruption *d & $\begin{array}{l}-1.299 \\
{[-1.55]}\end{array}$ & $\begin{array}{l}1.437 \\
{[1.47]}\end{array}$ & $\begin{array}{l}0.876 \\
{[0.86]}\end{array}$ & $\begin{array}{c}1.820^{* *} \\
{[2.39]}\end{array}$ & $\begin{array}{c}1.820^{* *} \\
{[2.39]}\end{array}$ & \\
\hline Log of Regulatory quality*d & $\begin{array}{l}0.014 \\
{[0.48]}\end{array}$ & $\begin{array}{l}-0.003 \\
{[-0.11]}\end{array}$ & $\begin{array}{l}0.006 \\
{[0.19]}\end{array}$ & $\begin{array}{l}-0.020 \\
{[-1.06]}\end{array}$ & $\begin{array}{l}-0.020 \\
{[-1.06]}\end{array}$ & \\
\hline Log of Government eff. ${ }^{* d}$ & $\begin{array}{c}2.286^{* * *} \\
{[3.21]}\end{array}$ & $\begin{array}{l}0.096 \\
{[0.10]}\end{array}$ & $\begin{array}{l}0.101 \\
{[0.10]}\end{array}$ & $\begin{array}{l}-0.826 \\
{[-1.11]}\end{array}$ & $\begin{array}{l}-0.826 \\
{[-1.11]}\end{array}$ & \\
\hline Log of Political risk.*d & $\begin{array}{l}0.144 \\
{[0.30]}\end{array}$ & $\begin{array}{l}1.536^{*} \\
{[1.81]}\end{array}$ & $\begin{array}{l}1.408^{*} \\
{[1.70]}\end{array}$ & $\begin{array}{l}0.454 \\
{[0.95]}\end{array}$ & $\begin{array}{l}0.454 \\
{[0.95]}\end{array}$ & \\
\hline Log of Voice and acc. ${ }^{*} d$ & $\begin{array}{l}-1.600 \\
{[-1.06]}\end{array}$ & $\begin{array}{c}-3.152^{* *} \\
{[-2.18]}\end{array}$ & $\begin{array}{c}-3.506^{* *} \\
{[-2.38]}\end{array}$ & $\begin{array}{c}-3.615^{* * *} \\
{[-3.93]}\end{array}$ & $\begin{array}{c}-3.615^{* * * *} \\
{[-3.93]}\end{array}$ & \\
\hline Log of Rule of law*d & $\begin{array}{l}-0.050 \\
{[-0.04]}\end{array}$ & $\begin{array}{l}-0.672 \\
{[-0.51]}\end{array}$ & $\begin{array}{l}-0.827 \\
{[-0.61]}\end{array}$ & $\begin{array}{c}-1.497^{*} \\
{[-1.67]}\end{array}$ & $\begin{array}{c}-1.497^{*} \\
{[-1.67]}\end{array}$ & \\
\hline SEE-Dummy & $\begin{array}{c}26.358^{* * * *} \\
{[4.89]}\end{array}$ & & & & & \\
\hline Constant & $\begin{array}{c}-28.15^{* * *} \\
{[-9.45]}\end{array}$ & $\begin{array}{l}-2.023 \\
{[-0.29]}\end{array}$ & $\begin{array}{l}-5.551 \\
{[-0.80]}\end{array}$ & $\begin{array}{c}-15.973 * * * \\
{[-3.11]}\end{array}$ & $\begin{array}{c}-31.174^{* * *} \\
{[-5.68]}\end{array}$ & $\begin{array}{l}-4.465 \\
{[-0.72]}\end{array}$ \\
\hline Observations & 1,932 & 1,932 & 1,932 & 1,932 & 1,932 & 1,932 \\
\hline R-squared & 0.707 & 0.777 & 0.780 & 0.921 & 0.921 & 0.917 \\
\hline Time dummy & Yes & No & Yes & Yes & Yes & Yes \\
\hline Host country dummy & No & Yes & Yes & No & Yes & Yes \\
\hline Source country dummy & No & Yes & Yes & No & Yes & Yes \\
\hline Country-pair (index) dummy & No & No & No & Yes & Yes & Yes \\
\hline
\end{tabular}

Notes: Dependent variable is log bilateral FDI stock. t-statistics in brackets, ${ }^{* * *},{ }^{* *}$ and ${ }^{*}$ indicate significance of coefficients at 1,5 and 10 per cent, respectively. 
Focusing on the most used specification, column 5 , we find that host country GDP and source country GDP is positive and significant. This suggests that the income level and the size of host and source country market is an important determinant for foreign investors. A negative and significant coefficient of distance indicates that FDI stocks are determined by gravity factors, as expected. On the other hand, the positive coefficient of host country GDP and the negative coefficient of distance support the market-seeking and efficiency-seeking hypothesis of FDI. The estimated gravity coefficients can be interpreted as follows. Source and host country GDP has a positive and significant impact on bilateral FDI stock, with an elasticity of 0.913 and 0.668 . An increase in source and host country GDP by 1 per cent increases bilateral FDI stock from source to host country on average by 1 and 0.7 per cent, respectively, ceteris paribus. The same estimates confirm that an increase in the road distance between capital cities of source and host country by 1 per cent will decrease bilateral FDI stock from source to host countries, on average, by 1.1 per cent, ceteris paribus. The findings from LSDV estimates (column 5) confirm the negative effect of the absolute difference of GDP per capita between countries on the size of bilateral FDI stock.

The estimated elasticity of the GDP per capita difference variable is -0.370 . However, other LSDV specifications with time invariant host country and source country fixed effects and time varying host country and source country fixed effects confirm the positive relationship of GDP per capita difference with bilateral FDI stock. The negative (positive) sign of this variable may be attributed to the fact that differences in wage levels between countries are (compensated) not compensated by productivity (Bergstrand 1989). Interpreting the result from pair fixed effects (column 5), a 1 per cent increase of GDP per capita absolute differences between countries is associated with, on average, a 0.37 per cent decrease of inward FDI stock in host countries, ceteris paribus. We find that the coefficient of the same country, indicating a common border, common language or cultural similarities between source and host country at the same time, are positively associated to bilateral FDI stock. The model predicts that bilateral FDI stock between countries that share a language, and cultural and border similarities at the same time is higher than bilateral FDI stock between countries that do not share these similarities (see model 5). The explanation of this result is that countries in the sample that are close to each other do have bilateral FDI activity much more than countries that are distant to each other. The argument holds, since there is a significant amount of bilateral
FDI activity between close countries of SEE- 5 and EU-NMS-10.

To capture the partial effect of institutional development on the size of the inward stock of FDI in SEE countries, the institutional variables are interacted with the SEE dummy variable. The estimated coefficient of transition progress for EU-NMS-10 countries in the equation of FDI is 3.395 per cent $\left(3.395-4.623^{*} 0\right)$, which is significant at a 5 per cent level of significance. For SEE- 5 countries it is -1.228 per cent $(3.395-4.623 * 1$ ). The difference is 4.623 per cent less for SEE- 5 countries is economically large and statistically significant at a 1 per cent level of significance. This result confirms the hypothesis that the size of bilateral FDI stock between EU-NMS-10 and SEE-5 countries varies with respect to transition progress development. The results confirm that a 10 per cent increase in transition progress, which is associated with advancements in the host country's transition reforms, increases (decreases) the size of bilateral FDI stock into host EU-NMS-10 (SEE-5) countries by 3.4 and 4.6 per cent, respectively, ceteris paribus.

The estimated elasticity of the control of corruption in EU-NMS-10 countries is $-0.203 \quad(-0.203+$ $1.820^{*} 0$ ) per cent, which is not significant. For SEE-5 countries it is 1.671 per cent $\left(-0.203+1.820^{*} 1\right)$. The difference of 1.820 percentage points more for SEE5 countries is statistically significant at a 5 per cent level of significance. The coefficient size, above 1 for SEE- 5 countries, of the control of corruption index indicates that foreign investors are sensitive to misuse of political power by host country elites and governments. Interpreting this result, 1 per cent increases of the extent to which public power is exercised for private gains through corruption channels leads to an increase of bilateral FDI stock in the host SEE-5 countries, on average, by 1.820 per cent, ceteris paribus. This result may be attributed to discriminatory corruption, which means that in exchange for a bribe the host country governments offer the briber services that are not supposed to be offered.

The same estimates confirm that the estimated coefficient of the CPI index for the EU-NMS-10 countries in the equation of FDI is -1.054 per cent $(-1.054+1.438 * 0)$. For SEE- 5 countries it is 0.384 per cent $\left(-1.054+1.438^{*} 1\right)$. The difference of 1.438 per cent, or one and a half percentage points more for SEE- 5 countries, is statistically significant at 1 per cent level of significance. These results indicate that a 1 per cent increase in the CPI index, which is associated with lower perceptions by the host country population toward the presence of corruption in the business environment, the size of bilateral FDI stock into host countries SEE- 5 countries increases by 0.38 per cent, 
ceteris paribus. On the other hand, the negative coefficient of the CPI index for the benchmark category of EU-NMS-10 countries indicates that bilateral FDI stock into EU-NMS-10 countries, originating from OECD-20 countries, decreases as the business environment in the former group of countries is perceived to be less corrupt.

The estimated elasticity of bilateral exports in robust LSDV estimates is 0.137 per cent. This result suggests that the increase of bilateral exports of host SEE-5 and EU-NMS-10 countries serves as a channel through which FDI activity in the exporting countries expand. Also, the positive relationship between bilateral exports and bilateral FDI stock, on the other hand, confirms the complementarities between bilateral exports and bilateral FDI stocks. The significant and positive coefficient of bilateral exports indicate that a 10 per cent increase in the bilateral exports from country $\mathrm{j}$ to country $\mathrm{i}$ (from SEE-5 and EU-NMS-10 to OECD-20), increase bilateral FDI stock from country $i$ to country $j$ (from OECD-20 to SEE-5 and EU-NMS-10), on average, by 1.3 per cent, ceteris paribus.

\subsubsection{Robustness check: discussion of results from alternative estimates}

Table 4 reports the results from PPML and RET estimates, columns 7 and 8 , as a robustness check to the LSDV estimates. Based on the likelihood-ratio test $\left(\chi^{2}\right)$ reported in the last row of each table, the estimated results from PPML and RET estimates are significant. The differences of the estimated coefficient size between different estimation techniques seems to suggest that these differences are driven either by the large number of zero observations in the sample or by heterogeneity of the data, based on the fact that in the selected sample we have included countries that are different with respect to macroeconomic development and their institutional level of development. Therefore, the presence of heterogeneity in the estimates raises the question of the best specified model.

To select the appropriate model we perform a Ramsey-RESET, which is applied by checking the significance of an additional regressor constructed as $\left(x^{\prime} b\right)^{2}$, where $b$ denotes the vector of estimated parameters. The $p$-value of this test is 2.61 in PPML and 5.79 in RET estimates, suggesting the selection of the RET estimates for interpreting the results.

In RET we find a significant effect from WTO membership. The enhancement effect of WTO membership is 25.48 per cent $^{7}$. Also, a bilateral FDI agreement has a strong effect in RET estimates (with an average enhancement effect of 19.96 per cent). The same results suggest a positive relationship between schooling
Table 4: Robustness check: Alternative estimates of the determinants of FDI stock

\begin{tabular}{|c|c|c|}
\hline VARIABLES & $\begin{array}{c}\text { (7) } \\
\text { Random } \\
\text { Effect Tobit }\end{array}$ & $\begin{array}{c}(8) \\
\text { Poisson } \\
\text { PPML }\end{array}$ \\
\hline Log of GDP in source c. (-1) & $\begin{array}{c}0.494^{* * *} \\
{[5.46]}\end{array}$ & $\begin{array}{c}0.087^{* * * *} \\
{[3.01]}\end{array}$ \\
\hline Log of GDP in host. c. (-1) & $\begin{array}{c}0.591^{* * *} \\
{[7.59]}\end{array}$ & $\begin{array}{c}0.102^{* * * *} \\
{[3.53]}\end{array}$ \\
\hline Log of diff. in GDPc (-1) & $\begin{array}{l}0.112 \\
{[1.22]}\end{array}$ & $\begin{array}{c}0.242^{* * * *} \\
{[6.79]}\end{array}$ \\
\hline Log of distance & $\begin{array}{c}-1.506^{* * * *} \\
{[-8.35]}\end{array}$ & $\begin{array}{c}-0.303^{* * *} \\
{[-6.13]}\end{array}$ \\
\hline Same country & $\begin{array}{l}0.892 \\
{[1.29]}\end{array}$ & $\begin{array}{l}0.059 \\
{[0.41]}\end{array}$ \\
\hline WTO membership & $\begin{array}{c}0.227^{* *} \\
{[2.26]}\end{array}$ & $\begin{array}{c}0.124^{* * *} \\
{[1.98]}\end{array}$ \\
\hline Bilateral FDI agreement & $\begin{array}{c}0.249^{*} \\
{[1.95]}\end{array}$ & $\begin{array}{c}0.182^{* *} \\
{[2.16]}\end{array}$ \\
\hline Log of bilateral exports $(-1)$ & $\begin{array}{c}0.217 * * * \\
{[6.27]}\end{array}$ & $\begin{array}{c}0.097^{* * * *} \\
{[5.18]}\end{array}$ \\
\hline Log of Schooling & $\begin{array}{c}0.574^{* * *} \\
{[4.59]}\end{array}$ & $\begin{array}{l}-0.090 \\
{[-1.49]}\end{array}$ \\
\hline Log of Transition progress & $\begin{array}{c}5.923^{* * * *} \\
{[8.13]}\end{array}$ & $\begin{array}{c}1.064^{* *} \\
{[2.52]}\end{array}$ \\
\hline Log of Corruption perc. index & $\begin{array}{c}-1.276^{* * *} \\
{[-5.02]}\end{array}$ & $\begin{array}{c}-0.364^{* *} \\
{[-2.57]}\end{array}$ \\
\hline Log of Control of corruption & $\begin{array}{l}-0.040 \\
{[-0.13]}\end{array}$ & $\begin{array}{c}0.369^{*} \\
{[1.80]}\end{array}$ \\
\hline Log of Regulatory quality & $\begin{array}{c}1.064^{* * * *} \\
{[2.58]}\end{array}$ & $\begin{array}{l}-0.115 \\
{[-0.46]}\end{array}$ \\
\hline Log of Government effectiveness & $\begin{array}{l}-0.157 \\
{[-0.44]}\end{array}$ & $\begin{array}{l}-0.251 \\
{[-1.24]}\end{array}$ \\
\hline Log of Political risk & $\begin{array}{l}-0.083 \\
{[-0.48]}\end{array}$ & $\begin{array}{l}-0.047 \\
{[-0.47]}\end{array}$ \\
\hline Log of Voice and accountability. & $\begin{array}{l}0.560 \\
{[1.04]}\end{array}$ & $\begin{array}{l}0.393 \\
{[1.40]}\end{array}$ \\
\hline Log of Rule of law & $\begin{array}{l}-0.161 \\
{[-0.53]}\end{array}$ & $\begin{array}{l}-0.022 \\
{[-0.12]}\end{array}$ \\
\hline Log of Corruption perc. index ${ }^{*} d$ & $\begin{array}{c}1.928^{* * *} \\
{[3.02]}\end{array}$ & $\begin{array}{c}0.826^{* *} \\
{[2.14]}\end{array}$ \\
\hline Log of Transition progress*d & $\begin{array}{c}-5.854^{* * *} \\
{[-5.05]}\end{array}$ & $\begin{array}{c}-1.666^{* *} \\
{[-2.13]}\end{array}$ \\
\hline Log of Control of corruption *d & $\begin{array}{c}1.344^{* *} \\
{[2.56]}\end{array}$ & $\begin{array}{l}-0.265 \\
{[-0.85]}\end{array}$ \\
\hline Log of Regulatory quality*d & $\begin{array}{l}-1.112 \\
{[-1.64]}\end{array}$ & $\begin{array}{l}-0.091 \\
{[-0.21]}\end{array}$ \\
\hline Log of Government eff.*d & $\begin{array}{l}0.052 \\
{[0.10]}\end{array}$ & $\begin{array}{c}0.587^{* *} \\
{[1.98]}\end{array}$ \\
\hline Log of Political risk. ${ }^{* d}$ & $\begin{array}{l}0.578 \\
{[1.55]}\end{array}$ & $\begin{array}{l}0.172 \\
{[0.90]}\end{array}$ \\
\hline Log of Voice and acc. ${ }^{*} d$ & $\begin{array}{c}-2.780^{* * *} \\
{[-3.74]}\end{array}$ & $\begin{array}{c}-0.913^{* *} \\
{[-2.18]}\end{array}$ \\
\hline SEE-Dummy & $\begin{array}{c}25.628^{* * * *} \\
{[8.02]}\end{array}$ & $\begin{array}{c}6.671^{* * *} \\
{[3.84]}\end{array}$ \\
\hline Constant & $\begin{array}{c}-25.822^{* * * *} \\
{[-9.55]}\end{array}$ & $\begin{array}{l}-7.25 \\
{[-4.62]}\end{array}$ \\
\hline Ramsey-reset test ( $p$-value) & 5.79 & 2.21 \\
\hline Cons_1 & & $\begin{array}{c}-5.941^{* * *} \\
{[-5.03]}\end{array}$ \\
\hline Cons_2 & & $\begin{array}{c}-2.640^{* * * *} \\
{[-14.21]}\end{array}$ \\
\hline $\begin{array}{l}\text { Prob> chi2 (Wald chi - square); } \\
\text { Log-likelihood }\end{array}$ & 0.000 & 0.000 \\
\hline Observations & 1,932 & 1,932 \\
\hline Number of groups & 203 & 203 \\
\hline
\end{tabular}

Notes: Dependent variable is log bilateral FDI stock. z-statistics in brackets, ${ }^{* *},{ }^{* *}$ and ${ }^{*}$ indicate significance of coefficients at 1,5 and 10 per cent, respectively. 
and FDI. The estimated elasticity of schooling in the RET estimates is 0.012 , indicating that a 10 per cent increase in tertiary school enrolment will increase bilateral FDI stock, from OECD-20 to SEE-5 and EU-NMS-10 countries, on average, by 0.1 per cent, ceteris paribus. This result supports efficiency-seeking considerations, that foreign investors are likely to locate their investments in countries with high potentials for efficient human resources and a well-educated labor force.

The estimated elasticity of the regulatory quality index for EU-NMS-10 countries is 1.064 (1.064-1.112*0) which is significant at a 1 per cent level of significance. For SEE- 5 countries it is -0.048 per cent (1.064$1.112^{*} 1$ ). The difference of $1.112 \%$ less for SEE- 5 countries is statistically insignificant. However, the index of regulatory quality for EU-NMS-10 countries above 1 indicates that the sensitivity of foreign investments coming from OECD-20 countries with respect to regulatory quality index developments in EU-NMS-10 countries is relatively high. The results indicate that a 1 per cent increase in regulatory quality index is associated with a 1.06 per cent increase of FDI stock in EUNMS-10 countries, ceteris paribus. This result suggests that sound regulation policies that promote private sector developments in EU-NMS-10 countries contribute to the accumulation of inward stock of FDI.

\subsubsection{Discussion of results from dynamic panel models}

In this section we use the generalized method of moments (GMM) estimator proposed by Arrellano-Bond (1991) and Arrellano-Bover (1995)/Blundell-Bond (1998) and suggested by Roodman (2006). In all cases the dependent variables, gross domestic product for host and source country and bilateral exports, are endogenous and other explanatory variables are treated as exogenous. We use the institutional-related variables as instrumental variables for the endogenous variables, in order to overcome the endogeneity problem. Following Roodman (2006), we exclude distance and dummy variables like: smctry, bilateral FDI agreement and WTO membership, since using all of the explanatory variables used in LSDV estimates increases the number of instruments, thus overfitting the endogenous variable (Roodman 2006).

In particularly, we use the system GMM estimates and report robust two - step GMM estimates which provides standard errors that are robust to heteroscedasticity and serial correlation (Roodman 2006). We address the downward bias of standard errors in a two-step GMM by using the proposed correction term by Windmeijer (2005), which is implemented by the xtabond2 Stata command.
Table 5: Robustness check: System GMM results

\begin{tabular}{|c|c|c|}
\hline VARIABLES & $\begin{array}{c}(9) \\
\text { System } \\
\text { GMM }\end{array}$ & $\begin{array}{c}(10) \\
\text { System } \\
\text { GMM }\end{array}$ \\
\hline Log of lagged dependent variable $(-1)$ & $\begin{array}{c}0.911^{* * *} \\
{[9.59]}\end{array}$ & $\begin{array}{c}0.657^{* * *} \\
{[5.86]}\end{array}$ \\
\hline Log of GDP in source country & $\begin{array}{l}-0.010 \\
{[-0.06]}\end{array}$ & $\begin{array}{l}0.138 \\
{[0.46]}\end{array}$ \\
\hline Log of GDP in host country & $\begin{array}{l}-0.121 \\
{[-0.34]}\end{array}$ & $\begin{array}{l}-0.146 \\
{[-0.18]}\end{array}$ \\
\hline Log of difference in GDP per capita & $\begin{array}{l}0.081 \\
{[0.71]}\end{array}$ & $\begin{array}{l}0.126 \\
{[0.27]}\end{array}$ \\
\hline Log of bilateral exports & $\begin{array}{l}0.104 \\
{[0.65]}\end{array}$ & $\begin{array}{l}0.279 \\
{[1.04]}\end{array}$ \\
\hline Log of schooling & $\begin{array}{l}0.142 \\
{[0.60]}\end{array}$ & $\begin{array}{l}1.354 \\
{[1.10]}\end{array}$ \\
\hline Log of transition progress & $\begin{array}{l}1.519 \\
{[0.55]}\end{array}$ & $\begin{array}{l}8.577 \\
{[1.40]}\end{array}$ \\
\hline Log of corruption perception index & $\begin{array}{l}-0.068 \\
{[-0.09]}\end{array}$ & $\begin{array}{l}2.874 \\
{[1.01]}\end{array}$ \\
\hline Log of control of corruption & $\begin{array}{l}-0.163 \\
{[-0.20]}\end{array}$ & $\begin{array}{l}-0.944 \\
{[-0.80]}\end{array}$ \\
\hline Log of regulatory quality & $\begin{array}{l}-0.569 \\
{[-0.33]}\end{array}$ & $\begin{array}{l}-2.912 \\
{[-0.74]}\end{array}$ \\
\hline Log of government effectiveness & $\begin{array}{l}-0.662 \\
{[-0.87]}\end{array}$ & $\begin{array}{l}-1.989 \\
{[-0.82]}\end{array}$ \\
\hline Log of political risk & $\begin{array}{l}-0.040 \\
{[-0.21]}\end{array}$ & $\begin{array}{l}-0.320 \\
{[-0.74]}\end{array}$ \\
\hline Log of voice and accountability & $\begin{array}{l}1.276 \\
{[0.93]}\end{array}$ & $\begin{array}{l}-0.069 \\
{[-0.02]}\end{array}$ \\
\hline Log of rule of law & $\begin{array}{l}-0.243 \\
{[-0.88]}\end{array}$ & $\begin{array}{l}-1.212 \\
{[-1.42]}\end{array}$ \\
\hline Log of corruption perception index ${ }^{*} d$ & $\begin{array}{l}0.006 \\
{[0.01]}\end{array}$ & $\begin{array}{l}2.417 \\
{[0.48]}\end{array}$ \\
\hline Log of transition progress*d & $\begin{array}{l}0.090 \\
{[0.07]}\end{array}$ & $\begin{array}{l}-4.823 \\
{[-0.88]}\end{array}$ \\
\hline Log of control of corruption*d & $\begin{array}{l}0.666 \\
{[1.17]}\end{array}$ & $\begin{array}{l}0.283 \\
{[0.15]}\end{array}$ \\
\hline Log of regulatory quality*d & $\begin{array}{l}0.323 \\
{[0.44]}\end{array}$ & $\begin{array}{l}1.743 \\
{[0.62]}\end{array}$ \\
\hline Log of government effectiveness ${ }^{*} d$ & $\begin{array}{l}0.293 \\
{[1.10]}\end{array}$ & $\begin{array}{l}1.378 \\
{[0.49]}\end{array}$ \\
\hline Log of political risk*d & $\begin{array}{l}-1.532 \\
{[-1.32]}\end{array}$ & $\begin{array}{l}-0.010 \\
{[-0.01]}\end{array}$ \\
\hline Log of voice and accountability & $\begin{array}{l}0.237 \\
{[0.19]}\end{array}$ & $\begin{array}{l}-0.048 \\
{[-0.01]}\end{array}$ \\
\hline Log of rule of law & $\begin{array}{c}0.911^{* * *} \\
{[9.59]}\end{array}$ & $\begin{array}{l}0.190 \\
{[0.99]}\end{array}$ \\
\hline Constant & $\begin{array}{l}-3.589 \\
{[-0.81]}\end{array}$ & $\begin{array}{l}1.491 \\
{[0.38]}\end{array}$ \\
\hline Observations & 1,687 & 1,687 \\
\hline Number of groups & 194 & 194 \\
\hline Arellano-Bond test for $\mathrm{AR}(1)$ & 0.000 & 0.000 \\
\hline Arellano-Bond test for $\mathrm{AR}(2)$ & 0.958 & 0.605 \\
\hline Number of instruments & 45 & 45 \\
\hline Wald statistics, p value & 0.000 & 0.000 \\
\hline Sargan test of overid. restrict, $p$ value & 0.458 & 0.560 \\
\hline
\end{tabular}

Notes: Dependent variable is log bilateral FDI stock. z-statistics in brackets, ${ }^{* * *},{ }^{* *}$ and ${ }^{*}$ indicate significance of coefficients at 1 , 5 and 10 per cent, respectively. Internal instruments are used for endogenous variables. Lag limits are $2 / 3$ for the lagged dependent variable and $3 / 4$ for endogenous regressors. The collapse option is always used. Year dummies are included but not shown. Column (10) shows the results with transformed dependent variable capturing the zero and negative observations in the matrix of the dependent variable. Lag limits are 2/3 for the lagged dependent variable and $3 / 4$ for endogenous regressors. 
The disadvantage of the system GMM is related to its causing the fast growth of the count of instruments with time dimensions, resulting in the overfit of the endogenous variable and the failure to remove the endogenous component (Roodman 2008). The presence of the endogenous component potentially can weaken the Sargan/Hansen statistics of overidentifying restrictions (Bowscher 2002). We use internal instruments for the lagged dependent variable to avoid the difficulty of finding valid external instruments. To deal with the instruments explosion, following Roodman (2008) we consider the lag limit of the dependent variable and other endogenous regressors and collapse the instruments.

The $p$-value of 0.00 of the Wald test in all specifications suggests rejection of the null hypothesis that the independent variables are jointly zero. The estimates from the robust system GMM are confirming the theoretically expected results. According to the results the estimated coefficient of the lagged dependent variable is positive and significant, suggesting that bilateral FDI stock is subject to persistence effects. The results confirm that the increase of the agglomeration effect of FDI by 10 per cent results in an increase of current FDI stock into host SEE- 5 and EU-NMS-10 countries by 9.1 per cent, ceteris paribus (column 9).

The fact that some of the significant explanatory variables reported in the static panel models become insignificant in the GMM specification, with the exception of the lagged dependent variable, suggest that some of the explanatory power of the lagged dependent variable is being falsely attributed to the other variables in static specification. Therefore, the empirical findings of the model imply that there exist some omitted dynamics in the static panel models, thus confirming that the empirical findings related to determinants of FDI in transition economies, using static panel models, should be accepted with caution.

\section{CALCULATING POTENTIAL INWARD FDI STOCK IN MACEDONIA}

To calculate the actual and potential bilateral FDI stock in Macedonia, we have considered the coefficients from robust LSDV estimates, accounting for the LSDV results without interaction terms (column 6, Table 3). The potential FDI stocks in Macedonia are calculated using the host country dummy coefficient of Macedonia, the source country dummy coefficients of different OECD-20 countries and year dummies.

The calculations of FDI potentials in Macedonia are considered for the period 2007-2015. Due to the fact that the end period of the data that is used for estimation purposes is 2010, the calculation of FDI potentials are considered up to 2010 based on the data provided for the dependent variable, actual FDI stocks and other explanatory variables used in model 6 . The calculation of FDI potentials for the period 2011-2015 is based on estimated data of bilateral FDI stock and other explanatory variables using a 3 year moving average calculation. In this regard, for the period 20112015 , for calculation purposes we have used the year dummy of 2010.

The values of actual and potential bilateral FDI stocks in Macedonia from the origin OECD-20 countries in total for the period 2007-2015 are presented in Table 6 . The results from Table 6 show that, according to the Gravity model (model 6), the actual FDI stock in Macedonia originating from OECD-20 countries is higher than the calculated potential FDI stock ${ }^{8}$. During the observed period, 2007-2010, we detect that actual inward FDI stock in Macedonia registered a constant increase.

Table 6: Actual and Potential FDI stock in Macedonia, originating from OECD-20 countries, in total

\begin{tabular}{|c|c|c|c|c|c|c|c|c|c|c|}
\hline & 2007 & 2008 & 2009 & 2010 & 2011 & 2012 & 2013 & 2014 & 2015 & Average \\
\hline Actual FDI stock & $2,035.2$ & $2,262.7$ & $2,521.5$ & $2,598.3$ & $2,460.8$ & $2,526.9$ & $2,528.6$ & $2,505.4$ & $2,520.3$ & $2,439.7$ \\
\hline Difference of act. FDI stock & & 227.4 & 258.8 & 76.7 & -137.4 & 66.0 & 1.7 & -23.2 & 14.8 & \\
\hline Percentage change of act FDI & & 11.1 & 11.4 & 3.0 & -5.2 & 2.6 & 0.1 & -0.9 & 0.6 & \\
\hline Potential FDI stock & $1,281.4$ & $1,729.7$ & $1,385.7$ & $1,802.1$ & $1,799.7$ & $1,793.0$ & $1,809.0$ & $1,803.6$ & $1,803.1$ & $1,689.7$ \\
\hline Difference of pot. FDI stock & & & & & -2.4 & -6.6 & 15.9 & -5.4 & -0.4 & \\
\hline Percentage change of pot FDI & & 34.9 & -19.8 & 30.0 & -0.1 & -0.3 & 0.8 & -0.3 & -0.0 & \\
\hline Ratio (Actual over Potential) & 1.6 & 1.3 & 1.8 & 1.4 & 1.4 & 1.4 & 1.4 & 1.4 & 1.4 & 1,4 \\
\hline Difference (Actual-Potential) & 753.8 & 532.9 & $1,135.8$ & 796.2 & 661.1 & 733.8 & 719.7 & 701.9 & 717.2 & 750.3 \\
\hline Percentage change (act-pot) & 58.8 & 30.8 & 82.0 & 44.2 & 36.7 & 40.9 & 39.8 & 38.9 & 39.8 & 45.7 \\
\hline
\end{tabular}

Notes: The data on actual and potential FDI stock in Macedonia are presented in total, in millions of US dollars. Actual and potential FDI stocks are summed up for each individual source OECD-20 country.

Source: own calculation, using estimations from gravity model (6) 
Figure 1: Ratio of actual-to-potential level of Macedonia's inward FDI-stock for the period 2007-2015, in total

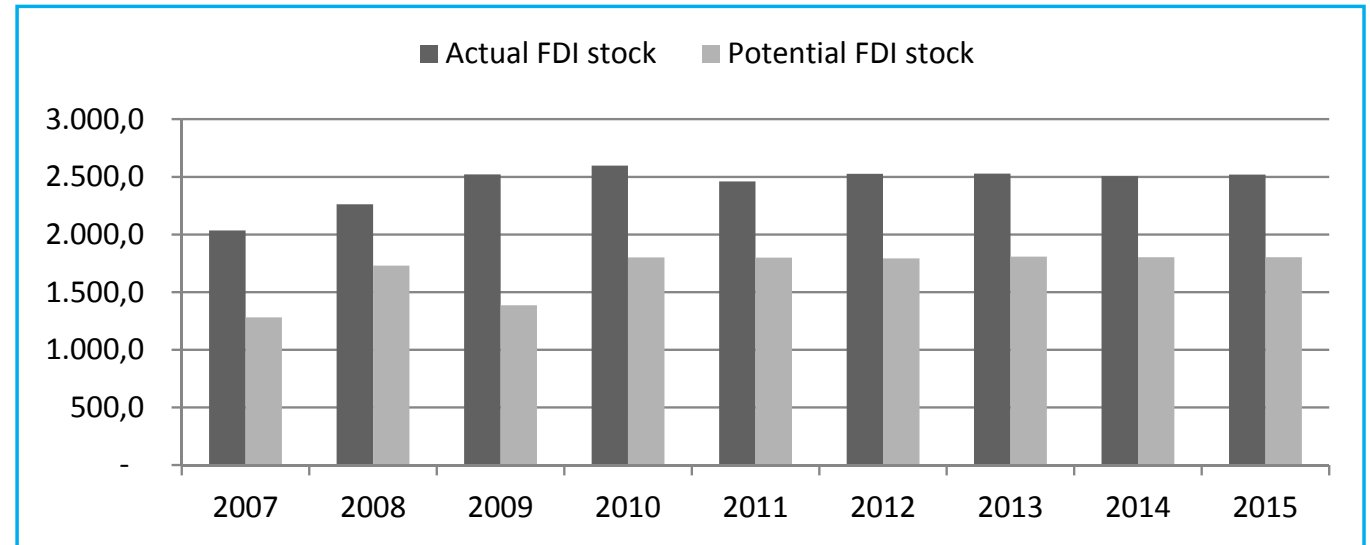

Source: OECD, 2014; own calculation

Analyzing by years after 2010, we observe that actual FDI stock, in total, recorded an increasing rate with decreasing tendency ${ }^{9}$, possibly due to global economic and financial turmoil, which clearly reduced the capabilities of Macedonia's economy to attract more FDI. This argument is reflected in the fact that from 2010 to 2011, the rate of total inward FDI stock in Macedonia originating from developed OECD-20 countries decreased by 5.2 per cent.

From 2007 to 2015, the total inward FDI stock in
Macedonia, on average, was realized approximately 45.7 per cent higher than the level predicted by the gravity model. This difference is relatively smaller in 2011, around 36.7 per cent, and much larger in 2009, around 82 per cent. As shown in Table 6, the ratio of actual to potential FDI stock is higher than 1 for the whole observed period, 2007-2015, confirming the fact that the actual FDI stock in Macedonia originating from OECD-20 countries, in total, was higher than the potential FDI stock predicted by the model (figure 1).

Table 7: FDI actual in Macedonia in the period 2007-2015, by country of origin (in millions of US dollars)

\begin{tabular}{|c|c|c|c|c|c|c|c|c|c|c|c|}
\hline & 2007 & 2008 & 2009 & 2010 & 2011 & 2012 & 2013 & 2014 & 2015 & Average & $\%$ \\
\hline Austria & 289.0 & 273.4 & 465.6 & 522.3 & 420.4 & 470.7 & 453.5 & 453.6 & 464.5 & 423.7 & 17.3 \\
\hline Belgium & 38.9 & 2.0 & 2.0 & 2.0 & 1.6 & 1.6 & 1.6 & 1.6 & 1.6 & 5.9 & 0.2 \\
\hline Canada & 3.4 & 4.4 & 4.1 & 5.5 & 4.7 & 4.7 & 4.9 & 4.8 & 4.8 & 4.6 & 0.2 \\
\hline Denmark & 1.0 & 2.0 & 2.0 & 2.4 & 2.1 & 2.2 & 2.2 & 2.2 & 2.2 & 2.0 & 0.1 \\
\hline Finland & 1.0 & 1.0 & 1.0 & 1.0 & 1.0 & 1.0 & 1.0 & 1.0 & 1.0 & 1.0 & 0.0 \\
\hline France & 12.1 & 18.1 & 37.7 & 173.0 & 76.3 & 95.7 & 115.0 & 95.7 & 102.1 & 80.6 & 3.3 \\
\hline Germany & 98.6 & 92.2 & 89.3 & 95.5 & 92.3 & 92.4 & 93.3 & 92.7 & 92.8 & 93.2 & 3.8 \\
\hline Greece & 622.8 & 599.7 & 527.7 & 515.7 & 547.7 & 530.4 & 531.2 & 536.4 & 532.7 & 549.4 & 22.5 \\
\hline Ireland & 1.0 & 1.0 & 1.0 & 1.0 & 1.0 & 1.0 & 1.0 & 1.0 & 1.0 & 1.0 & 0.0 \\
\hline Israel & 6.3 & 5.8 & 5.7 & 5.8 & 5.8 & 5.8 & 5.8 & 5.8 & 5.7 & 5.8 & 0.2 \\
\hline Italy & 53.4 & 77.3 & 80.5 & 78.2 & 78.7 & 78.7 & 78.6 & 78.8 & 8.8 & 75.9 & 3.1 \\
\hline Netherland & 494.8 & 606.2 & 754.2 & 735.5 & 698.6 & 729.5 & 721.1 & 716.4 & 722.3 & 686.5 & 28.1 \\
\hline Norway & 1.0 & 1.0 & 1.0 & 1.0 & 1.0 & 1.0 & 1.0 & 1.0 & 1.0 & 1.0 & 0.0 \\
\hline Portugal & 2.6 & 3.2 & 2.3 & 2.1 & 2.5 & 2.3 & 2.2 & 2.4 & 2.3 & 2.4 & 0.1 \\
\hline Spain & 1.0 & 1.0 & 1.0 & 1.0 & 1.0 & 1.0 & 1.0 & 1.0 & 1.0 & 1.0 & 0.0 \\
\hline Switzerland & 245.1 & 283.0 & 289.7 & 198.9 & 257.2 & 248.6 & 234.9 & 246.9 & 243.5 & 249.8 & 10.2 \\
\hline Sweden & 4.0 & 4.2 & 5.1 & 6.8 & 5.4 & 5.8 & 6.0 & 5.7 & 5.8 & 5.4 & 0.2 \\
\hline Turkey & 51.3 & 60.6 & 71.3 & 64.1 & 65.3 & 66.9 & 65.4 & 65.9 & 66.1 & 64.1 & 2.6 \\
\hline UK & 92.5 & 159.8 & 110.5 & 137.0 & 135.8 & 127.8 & 133.5 & 132.4 & 131.2 & 128.9 & 5.3 \\
\hline USA & 52.7 & 67.4 & 69.9 & 49.7 & 62.3 & 60.7 & 57.6 & 60.2 & 59.4 & 60.0 & 2.5 \\
\hline Total & 2072.2 & 2263.3 & 2521.7 & 2598.7 & 2460.8 & 2527.7 & 2511.4 & 2505.4 & 2520.3 & 2442.4 & 100.0 \\
\hline
\end{tabular}

Notes: Actual FDI stock data is the inward FDI stock in Macedonia from OECD-20 countries: FDI/TNC database, based on data from the National Bank of the Republic of Macedonia.

Source: National Bank of Republic of Macedonia. 
Table 8: FDI potentials in Macedonia in the period 2007-2015, by country of origin (in millions of US dollars)

\begin{tabular}{|c|c|c|c|c|c|c|c|c|c|c|c|}
\hline & 2007 & 2008 & 2009 & 2010 & 2011 & 2012 & 2013 & 2014 & 2015 & Average & $\%$ \\
\hline Austria & 59.6 & 76.5 & 70.8 & 84.2 & 80.1 & 81.0 & 81.9 & 81.0 & 81.3 & 77.4 & 4.6 \\
\hline Belgium & 38.9 & 50.5 & 43.6 & 52.2 & 51.2 & 50.7 & 51.4 & 51.1 & 51.1 & 48.9 & 2.9 \\
\hline Canada & 29.7 & 36.3 & 34.8 & 37.9 & 36.4 & 36.4 & 36.9 & 36.6 & 36.6 & 35.7 & 2.1 \\
\hline Denmark & 41.8 & 50.7 & 52.0 & 53.4 & 52.6 & 52.5 & 52.7 & 52.4 & 52.5 & 51.1 & 3.0 \\
\hline Finland & 38.8 & 46.6 & 46.7 & 9.2 & 34.2 & 30.0 & 24.5 & 29.5 & 28.0 & 31.7 & 1.9 \\
\hline France & 63.5 & 85.3 & 79.1 & 94.6 & 90.0 & 90.9 & 92.0 & 91.0 & 91.4 & 86.4 & 5.1 \\
\hline Germany & 105.9 & 148.2 & 96.6 & 169.4 & 159.5 & 162.0 & 164.2 & 162.0 & 162.9 & 147.8 & 8.7 \\
\hline Greece & 112.6 & 159.0 & 103.6 & 182.6 & 171.8 & 173.8 & 176.5 & 174.2 & 175.0 & 158.8 & 9.4 \\
\hline Ireland & 38.9 & 45.4 & 44.6 & 50.0 & 47.9 & 48.2 & 48.8 & 48.3 & 48.4 & 46.7 & 2.8 \\
\hline Israel & 27.7 & 34.7 & 34.8 & 37.9 & 35.9 & 36.2 & 36.7 & 36.2 & 36.4 & 35.1 & 2.1 \\
\hline Italy & 214.0 & 314.0 & 194.5 & 360.2 & 339.8 & 344.3 & 349.2 & 344.8 & 346.4 & 311.9 & 18.5 \\
\hline Netherland & 76.8 & 103.2 & 82.7 & 113.1 & 108.3 & 109.3 & 110.5 & 109.4 & 109.8 & 102.5 & 6.1 \\
\hline Norway & 35.8 & 43.8 & 44.1 & 46.8 & 45.0 & 45.3 & 45.7 & 45.3 & 45.5 & 44.1 & 2.6 \\
\hline Portugal & 35.3 & 42.4 & 40.6 & 45.2 & 43.2 & 43.4 & 44.0 & 43.5 & 43.6 & 42.4 & 2.5 \\
\hline Spain & 44.9 & 62.4 & 51.2 & 65.8 & 64.2 & 63.8 & 64.7 & 64.2 & 64.3 & 60.6 & 3.6 \\
\hline Sweden & 39.2 & 47.3 & 44.8 & 49.1 & 47.6 & 47.6 & 48.1 & 47.8 & 47.8 & 46.6 & 2.8 \\
\hline Switzerland & 39.7 & 50.1 & 48.2 & 56.8 & 52.9 & 53.8 & 54.6 & 53.8 & 54.1 & 51.5 & 3.1 \\
\hline Turkey & 136.1 & 197.5 & 159.1 & 156.0 & 202.3 & 188.5 & 189.8 & 195.5 & 191.7 & 179.6 & 10.6 \\
\hline UK & 55.9 & 78.3 & 61.8 & 79.7 & 78.9 & 78.3 & 79.2 & 78.8 & 78.8 & 74.4 & 4.4 \\
\hline USA & 46.4 & 57.7 & 52.1 & 58.1 & 57.9 & 57.0 & 57.8 & 57.6 & 57.5 & 55.8 & 3.3 \\
\hline Total & $1,281.4$ & $1,729.7$ & $1,385.7$ & $1,802.1$ & $1,799.7$ & $1,793.0$ & $1,809.0$ & $1,803.6$ & $1,803.1$ & $1,689.7$ & 100.0 \\
\hline
\end{tabular}

Notes: The data on potential FDI stock are calculated using the estimations from model 6.

Source: own calculation. Data on FDI potentials for the period 2011-2015 are based on estimated data

The data on actual FDI stock presented in Table 7 confirm that the highest level of inward FDI stock in Macedonia, between the period 2007-2015, on average, was recorded from countries relatively close to Macedonia: Netherland (28 per cent), Greece (22.6 per cent), Austria (17.3 per cent) and Switzerland (10.3 per cent).

The data on potential FDI stock, confirm that during the observed period 2007-2015, the highest level of potential FDI stock in Macedonia, is recorded from Italy (18.5 per cent), Turkey (10.6 per cent), Greece (9.4 per cent) and Germany (8.7 per cent).

In other words, the data confirm that relatively more distant OECD countries recorded less actual FDI stock and high potentials of FDI stock in Macedonia, once again confirming that actual FDI stock in Macedonia is significantly determined from gravitational attraction.

The comparison of actual and potential bilateral FDI stocks is presented in Table 9. Observing by individual OECD-20 origin countries of FDI, the data confirm the relatively strong gravitational character of Macedonian inward FDI stock, as outlined by the indicator of actual to potential FDI stock in Macedonia in Table 9. The comparisons show that based on the gravity model (model 6), the realized level of FDI stock is over potential during the years from 2007 to 2015 for some of the OECD-20 countries, such as Austria, Greece, Netherland and Switzerland (see Table 9).

In general, the main factors that contribute the most to closing the gap between potential and realized FDI stock for countries that show a high realization degree of FDI stock in Macedonia are the gravityrelated factor of distance and other gravity- related factors proxying for GDP and GDP per capita in the source countries. This judgment is supported by the fact that less distant countries to Macedonia that are economically well developed possess relatively large market sizes: Greece, Austria, Switzerland and the Netherland have shown high realization levels of FDI stocks in Macedonia. 
Table 9: Actual to potentials FDI in Macedonia in the period 2007-2015, by country of origin

\begin{tabular}{lccccccccc}
\hline & 2007 & 2008 & 2009 & 2010 & 2011 & 2012 & 2013 & 2014 & 2015 \\
\hline Austria & 4.9 & 3.6 & 6.6 & 6.2 & 5.2 & 5.8 & 5.5 & 5.6 & 5.7 \\
Belgium & 1.0 & 0.0 & 0.0 & 0.0 & 0.0 & 0.0 & 0.0 & 0.0 & 0.0 \\
Canada & 0.1 & 0.1 & 0.1 & 0.1 & 0.1 & 0.1 & 0.1 & 0.1 & 0.1 \\
Denmark & 0.0 & 0.0 & 0.0 & 0.0 & 0.0 & 0.0 & 0.0 & 0.0 & 0.0 \\
Finland & 0.0 & 0.0 & 0.0 & 0.1 & 0.0 & 0.0 & 0.0 & 0.0 & 0.0 \\
France & 0.2 & 0.2 & 0.5 & 1.8 & 0.8 & 1.1 & 1.3 & 1.1 & 1.1 \\
Germany & 0.9 & 0.6 & 0.9 & 0.6 & 0.6 & 0.6 & 0.6 & 0.6 & 0.6 \\
Greece & 5.5 & 3.8 & 5.1 & 2.8 & 3.2 & 3.1 & 3.0 & 3.1 & 3.0 \\
Ireland & 0.0 & 0.0 & 0.0 & 0.0 & 0.0 & 0.0 & 0.0 & 0.0 & 0.0 \\
Israel & 0.2 & 0.2 & 0.2 & 0.2 & 0.2 & 0.2 & 0.2 & 0.2 & 0.2 \\
Italy & 0.2 & 0.2 & 0.4 & 0.2 & 0.2 & 0.2 & 0.2 & 0.2 & 0.2 \\
Netherland & 6.4 & 5.9 & 9.1 & 6.5 & 6.5 & 6.7 & 6.5 & 6.5 & 6.6 \\
Norway & 0.0 & 0.0 & 0.0 & 0.0 & 0.0 & 0.0 & 0.0 & 0.0 & 0.0 \\
Portugal & 0.1 & 0.1 & 0.1 & 0.0 & 0.1 & 0.1 & 0.1 & 0.1 & 0.1 \\
Spain & 0.0 & 0.0 & 0.0 & 0.0 & 0.0 & 0.0 & 0.0 & 0.0 & 0.0 \\
Sweden & 0.1 & 0.1 & 0.1 & 0.1 & 0.1 & 0.1 & 0.1 & 0.1 & 0.1 \\
Switzerland & 6.2 & 5.7 & 6.0 & 3.5 & 4.9 & 4.6 & 4.3 & 4.6 & 4.5 \\
Turkey & 0.4 & 0.3 & 0.4 & 0.4 & 0.3 & 0.4 & 0.3 & 0.3 & 0.3 \\
UK & 1.7 & 2.0 & 1.8 & 1.7 & 1.7 & 1.6 & 1.7 & 1.7 & 1.7 \\
USA & 1.1 & 1.2 & 1.3 & 0.9 & 1.1 & 1.1 & 1.0 & 1.0 & 1.0 \\
\hline S & & & & & & & & \\
\end{tabular}

Source: own calculation.

Figure 2 presents the ratios of realized to potential FDI for selected years. The ratio of actual to potential FDI below 1 shows that Macedonia received less FDI than is predicted by the model. Also, there exists more scope for receiving new FDI. The ratio of actual to potential FDI above 1 shows that it has received more FDI than potentially expected.

Regarding the selection of explanatory variables in the model (GDP, GDP per capita, distance, same country, bilateral FDI agreement, WTO membership, bilateral exports, corruption perception index, schooling, transition progress and governance indicators), it can be said that the Macedonian capacity to induce economic growth and structural reforms, and continue with institutional reforms, will appear as the critical factors in attracting more FDI in the future.

Figure 2: Ratio of potential-to-realized level of Macedonian inward FDI-stock between the years 2007and 2015, by country of origin

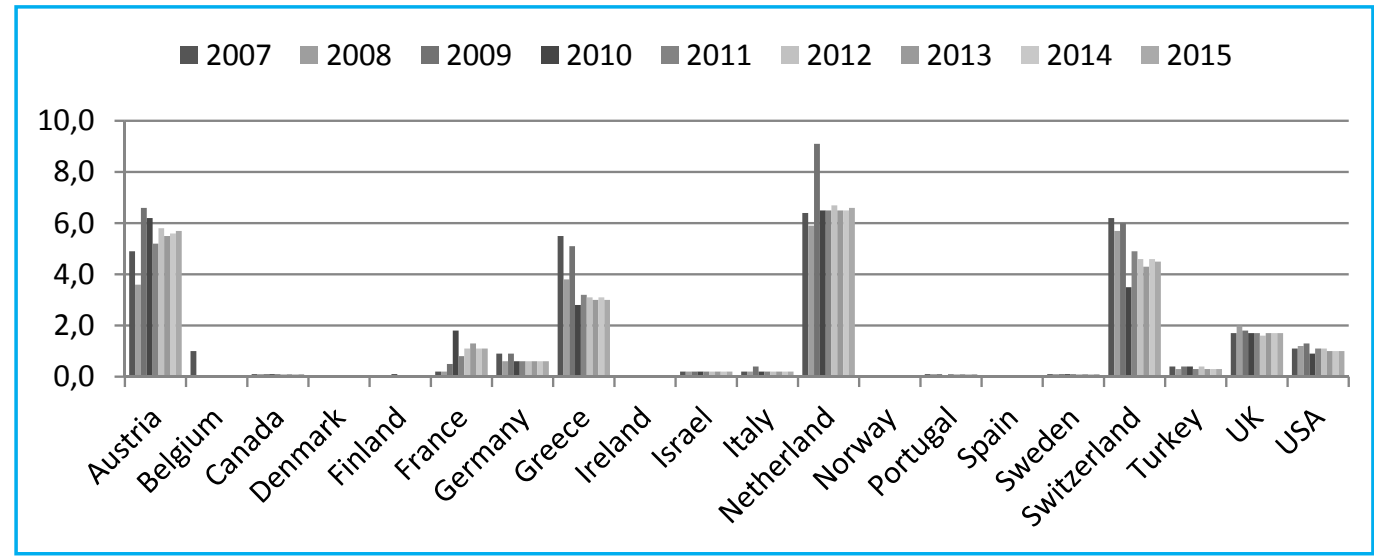

Source: OECD, 2014; own calculation 


\section{CONCLUSIONS}

This paper has identified significant institutional determinants ofFDI stocks into host countries of SEE5 and EU-NMS-10, and highlighted theimplications of different institutional factors for FDI stocks. Using an augmented Gravity Model, we focused the research mainly on the importance of gravity and institutional factors as primary determinants of FDI in host countries. As expected, all of these determinants play an important role in determining a firm's foreign market entry decision. Moreover, host country institutionalrelated factors appeared to significantly determine bilateral FDI stock from the OECD-20 countries. The estimates show that gravity factors like market size and income level-related variables are important determinants of FDI. The negative and significant coefficient of distance indicates that, as expected, FDI is determined by gravity factors. Moreover, the study confirms that a foreign investor's motives toward SEE- 5 and EUNMS-10 are driven by market seeking considerations.

Based on a panel data analysis we have found that FDI stocks into SEE-5 and EU-NMS- 10 countries are significantly influenced by both gravity factors (distance, GDP in host country, GDP in source country, cultural, language and border similarities) and non-gravity factors (bilateral exports, schooling, transition progress CPI index, control of corruption, regulatory quality, WTO membership and bilateral FDI agreement). The positive and significant coefficients of market size factors (GDP) for both source and host country indicates that FDI is determined by host and source country market seeking considerations. Also, the positive and significant coefficients of schooling are a signal that foreign investors are considering efficiency - seeking considerations for positive FDI decisions.

The results of the study confirm the importance of institutions for FDI stocks in SEE-5 and EU-NMS-10 countries. The LSDV estimates predict that bilateral FDI stock between SEE-5 and EU-NMS-10 countries vary with respect to development in transition progress, CPI index and control of corruption. The robustness check estimates, using RET results, based on a transformed dependent variable, confirm the importance of institutional-related factors for the size of bilateral FDI stock. These estimates suggest that bilateral FDI stock into SEE-5 and EU-NMS-10 countries is also determined by host country WTO membership and bilateral FDI agreement. Also, the findings from RET estimates confirm that the size of inward FDI stock between SEE- 5 and EU-NMS-10 countries vary with respect to regulatory quality index, i.e., perceptions of SEE-5 and EU-NMS-10 countries' governments' ability to promote private sector development.

The estimated values of potential FDI in Macedonia reveal that a further increase in inward FDI can be achieved only upon realization of further economic growth and better improvement of transition and institutional specific factors. Therefore, Macedonia's institutions should be focused on creating conditions for sustainable economic growth, thus reducing the gap between the actual level of FDI in Macedonia and its potential level from source OECD-20 countries.

The findings of the study can provide an analytical foundation for the evaluation of country policies and institutions aimed at making SEE-5 and EU-NMS-10 countries more attractive to foreign investors. The findings also suggest that strong emphasis should be placed by host country policy makers in improving the efficiency of government institutions, controlling corruption and bureaucracy and improving general economic conditions. These should also help policy makers in designing strategies for attracting more FDI.

\section{References}

Agarwal, S., Ramaswami, S. N. 1992. Choice of foreign market entry mode: impact of ownership, location and internationalization factors. Journal of International Business Studies 23(1): 1-27.

Arellano, M., Bond, S. 1991. Some Tests of Specification for Panel Data: Monte Carlo Evidence and an Application to Employment Equations. The Review of Economic Studies 58 (2): 277-297

Arellano, M., Bover, O. 1995. Another Look at the Instrumental Variable Estimation of Error-Components Models. Journal of Econometrics 68 (1): 29-51.

Baldwin, R., Taglioni, D. 2006. Gravity for dummies and dummies for gravity equations. National Bureau of Economic Research. Working Paper 12516, NBER

Bevan, A., Estrin, S. 2000. The Determinants of Foreign Direct Investment in Transition Economies. William Davidson Institute. Working Paper 342.

2004. The determinants of foreign direct investment into European transition economies. Journal of Comparative Economics 32 (4): 775-787.

Bergstrand, J. H. 1989. The Generalized Gravity Equation, Monopolistic Competition and the Factor-Proportions Theory in International Trade. The Review of Economics and Statistics 71(1): 141-153.

Borensztein, E., De Gregorio, J-W. L. 1998. How does foreign direct investment affect economic growth? Journal of International Economics 45(1): 115-135.

Botrić, V., Škuflić, L. 2006. Main Determinants of Foreign Direct Investment in the Southeast European Countries. Transition Studies Review 13(2): 359-377. 
Bowsher, C. G. 2002. On Testing Over identifying Restrictions in Dynamic Panel Data Models. In: Economics Letters 77(2): 211-220.

Blundell, R., Bond, S. 1998. Initial Conditions and Moment Restrictions in Dynamic Panel Data Models. Journal of Econometrics 87(1): 115-143.

Dauti, B. 2015. Determinants of Foreign Direct Investment in South East European Countries and New Member States of European Union Countries. Economic and Business Review 17 (1): 93-115

Derado, D. 2013. Determinants of FDI in transition countries and estimation of the potential level of Croatian FDI. Financial Theory and Practice 37(3): 227-258.

Demekas, D. G., Horváth, B., Ribakova, E., Wu, Y. 2005. Foreign Direct Investment in Southeastern Europe: How (and How Much) Can Policies Help. IMF Working Paper $.05 / 110$.

Estrin, S., Uvalic, M. 2013. Foreign direct investment into transition economies: Are the Balkans different? LSE «Europe in Question> Discussion Paper Series. LEQS Paper, (64).

Feenstra, Robert. C. 2004. Advanced International Trade: Theory and Evidence, Princeton, NJ: Princeton University Press.

Fidrmuc, J., Fidrmuc, J. 2003. Disintegration and Trade. Review of International Economics 11(5): 811-829.

Frankel, J., Stein, E., Wei, S. J. 1995. Trading Blocs and the Americas: The Natural, the Unnatural, and the Supernatural. Journal of Development Economics 47 (1): 61-95.

Globerman, S., Shapiro, D. 2002. Global Foreign Direct Investment Flows: The Role of Governance Infrastructure. World Development 30(11): 1899-1919.

Gorbunova,Y., Infante, D., Smirnova, J. 2012. New Evidence on FDI Determinants: An appraisal over the transition period. Prague Economic Papers 31(1): 65-76.

Guerin, S. 2006. The Role of Geography in Financial and Economic Integration: A Comparative Analysis of Foreign Direct Investment, Trade and Portfolio Investment Flows. The World Economy 29(2): 189-209.

Greene, W. H. 2013. Econometric Analysis (5th ed). Upper Saddle River, N.J.: Prentice Hall.

Hill, C., Hwang, P., Kim, W.C. 1990. An Eclectic Theory of the Choice of International Entry Mode. Strategic Management Journal 11(2): 117-128.

Holland, D., Pain, N. 1998. The determinants and impact of foreign direct investment in the transition economies: a panel data analysis. In V. Edwards (Ed), Convergence or Divergence. Aspirations and Reality in Central and Eastern Europe and Russia, Proceedings of 4th Annual conference, Centre for Research into East European Business.

Henderson, D., Daniel, M. 2008. Is gravity linear? Journal of Applied Economics 23(2): 137-172
Itaki, M. 1991. A Critical Assessment of the Eclectic Theory of the Multinational Enterprise. Journal of International Business Studies 22(3): 445-460.

Johnson, A. 2006. FDI inflows to the Transition Economies of Eastern Europe: Magnitude and Determinants. The Royal Institute of Technology, CESIS (Centre for Excellence for Studies in Science in Innovation), Paper No, 59.

Kinoshita, Y., Campos, N. F. 2004. Estimating the determinants of foreign direct investment inflows: how important are sampling and omitted variable biases? BOFIT Discussion Paper No.10, Bank of Finland, Institute for Economies in Transition, Helsinki, Finland.

Mateev, M. 2008. Determinants of Foreign Direct Investment in Central and Southeastern Europe: New Empirical Tests. Oxford Journal 8(1): 133-149.

Mora, M. N., Sahay, M. R., Zettelmeyer, M. J., Garibaldi, M. P. 2002. What Moves Capital to Transition Economies? (No. 2-64). International Monetary Fund.

Mrak, M., Rojec, M. 2013. EU Accession as an instrument of Speeding up Transition; in Routledge Handbook on The Economics and Political Economy of Transition, edited by Gerard Turley and Paul Hare.

Nilsson, L. 2000. Trade integration and the EU economic membership criteria. European Journal of Political Economy 16 (4): 807-827.

Peracchi, F., Viviano, E. 2004. An Empirical Micro Matching Model with an Application to Italy and Spain. Temi di discussione (Economic working papers) 538, Bank of Italy, Economic Research and International Relations Area.

Razin, A. 2001. FDI flows: a critical look. Pinhas Sapir Center for Development, Tel-Aviv University.

Resmini, 2000. The Determinants of Foreign Direct Investment in the CEECs: New evidence from sectoral patterns. Economics of Transition 8(3): 665-689.

Roodman, D. 2006. How to Do Xtabond2: An Introduction to "Difference" and "System" GMM in Stata. Center for Global Development Working Paper, (103).

Roodman, D. 2008. A Note on the Theme of Too Many Instruments. Oxford Bulletin of Economics and Statistics 71(1): 135-158.

Rose, A. K., Van Wincoop, E. 2001. National money as a barrier to international trade: the real case for currency union. American Economic Review 91(2): 386-390

Seric, A. 2011. Determinants of FDI location in Central and Eastern Europe (CEE). OECD Journal: General Papers 2010 (2): 77-90.

Silva, J. S., Tenreyro, S. 2006. The Log of Gravity. The Review of Economics and Statistics 88(4): 641-658. 2008. Trading Partners and Trading Volumes: Implementing the Helpman-Melitz-Rubinstein Model Empirically. Discussion Paper 662, University of Essex. 
Westerlund, J., Wilhelmsson, F. 2009. Estimating the gravity model without gravity using panel data. Applied Economics 43(6): 641-649.

Windmeijer, F. 2005. A finite sample correction for the variance of linear efficient two-step GMM estimators. Journal of Econometrics 126 (1): 25-51.

Zulfiu, M. 2008. Determinants of Foreign Direct Investment in Transition Economies: With Particular Reference to Macedonia's Performance, FIW Working Paper, No. 19.

\section{(Endnotes)}

1 The explanatory variables considered in this paper are similar to another paper which has been published in the Economic and Business Review (EBR), Vol 17(1), 2015; Faculty of Economics, University of Ljubljana. However, this paper differs significantly from the other one in terms of the considered sample size, literature review section and econometric methodologies. The dependent variable is: Bilateral FDI stock from OECD-20 countries to SEE-5 and EU-NMS-10 countries, whereas the dependent variable in the EBR paper is: Bilateral FDI stock from EU-14 countries to SEE- 5 and EU-NMS-10 countries. Using the estimated LSDV coefficients, this paper also contributes to calculating FDI potentials in Macedonia, from origin OECD-20 countries.

2 Description of the variables used in the empirical model is given in appendix1. Descriptive statistics of the variables employed in the model is given in appendix 2. Correlation matrix of the variables used in the model is given in appendix 3.

3 To avoid this problem we transform the FDI stock variable. To account for possible zero and negative observations, we have transformed the dependent variable by treating the negative observations of bilateral FDI data as zero values. A transformed dependent variable is used in robustness check estimates: i.e Random Effect Tobit Estimates and Poisson - Pseudo Maximum Likelihood Estimates.

4 With aggregate data, at country level, there is more reason to focus on bilateral differences in comparative advantages and tastes (reflected by the absolute differences in GDP per capita) to explain aggregate bilateral FDI between different countries, with respect to income level. This is a reflection that all countries possess comparative advantages or preferences for something.
5 The source of this variable is http://www.geobytes. com.

6 System GMM is more persistent than difference GMM particularly with a higher persistence of the dependent variable and a lower time dimension (Blundell and Bond, 1998), The improvement in efficiency is enhanced by the ability of system GMM to use more information by generating more instruments not only for the lagged dependent variable, but for other regressors as well, which might themselves exhibit high inertia.

7 The formula to compute this effect is $\left(e^{b_{i}}-1\right) \times 100$, where ${ }^{i}$ is the estimated coefficient

8 Potential FDI-stock is obtained as the value which would prevail if the entire Macedonian inward FDI would be determined by variables and parameters estimated by the model (Nilsson, 2000; Fidrmuc and Fidrmuc, 2003; Derado, 2013)

9 The increasing rate of inward FDI stock in Macedonia, in total from 2010 to 2011 although is positive (3.04 per cent), this rate of increase is low in comparison to the registered increase of inward FDI stock in Macedonia, from 2007 to 2008, and from 2008 to 2009, by 11.1 and 11.1 per cent, respectively. 
APPENDIX 1: Description of variables used in the model and data sources.

\begin{tabular}{|c|c|c|}
\hline $\begin{array}{l}\text { Variable } \\
\text { name }\end{array}$ & Measurement unit & Source \\
\hline Infdiijt & $\begin{array}{l}\text { Outward FDI stock from source country: FDI stock from source country to host } \\
\text { country at current year, in millions of US dollars }\end{array}$ & OECD \\
\hline Ingdpi,t & GDP in source country, millions of US dollars & UNCTAD \\
\hline Ingdpj,t & GDP in host country, millions of US dollars & UNCTAD \\
\hline Indifgdpcij,t & $\begin{array}{l}\text { Difference in GDP per capita between source country and host country, in PPP } \\
\text { (constant } 2005 \text { international\$), in logarithm }\end{array}$ & World Bank \\
\hline Indij & $\begin{array}{l}\text { Distance in kilometers between capital cities of host and source countries, in } \\
\text { logarithm }\end{array}$ & www.geobytes.com \\
\hline smctry & $\begin{array}{l}\text { Dummy variables that take value one when two countries share a border, a lan- } \\
\text { guage or were the same country in the past, correspondingly and zero otherwise }\end{array}$ & CEPII \\
\hline lbexijt-1 & Bilateral exports from country $\mathrm{j}$ to country $\mathrm{i}$. In millions of US dollars & OECD \\
\hline wtojt & $\begin{array}{l}\text { World Trade Organization membership of host country. Dummy variable }=1 \text { at } \\
\text { the time of host country accession into WTO at year } t, 0 \text { otherwise }\end{array}$ & UNCTAD \\
\hline bfdiaij & $\begin{array}{l}\text { Bilateral Investment agreement. Dummy variable }=1 \text {, denoting the year of entry } \\
\text { into force of bilateral investment agreement, at the time afterward, } 0 \text { otherwise }\end{array}$ & UNCTAD \\
\hline Inschjt & School enrollment, tertiary (\% gross) & World Bank \\
\hline Ltransjt & $\begin{array}{l}\text { Log of transition progress. The sum of the indexes of overall infrastructure re- } \\
\text { forms, banking reforms, trade and foreign exchange rate reforms and the index } \\
\text { of the securities and non - bank financial institutions }\end{array}$ & EBRD \\
\hline Lcpijt & Log of corruption perception index, range 0 - 10 & $\begin{array}{l}\text { Transparency } \\
\text { International }\end{array}$ \\
\hline Inccjt & Control of corruption in host country, in per centile rank, in logarithm & World Bank. WGI \\
\hline Inrqjt & Regulatory Quality in host country, in per centile rank, in logarithm & World Bank. WGI \\
\hline Lgovjt & Government effectiveness, in per centile rank, in logarithm & World Bank. WGI \\
\hline Inrljt & Rule of law in host country, in per centile rank, in logarithm & World Bank. WGI \\
\hline Lpsjt & Political risk, in per centile rank, in logarithm & World Bank. WGI \\
\hline Invajt & Voice and accountability in host country, in per centile rank, in logarithm & World Bank. WGI \\
\hline SEE-dummy & $\begin{array}{l}\text { SEE- } 5 \text { equal } 1 \text { for SEE- } 5 \text { countries; } 0 \text { - otherwise, capturing the benchmark cat- } \\
\text { egory of EU-NMS-10 countries }\end{array}$ & Own knowledge \\
\hline
\end{tabular}


APPENDIX 2: Descriptive statistics of the estimated coefficients

\begin{tabular}{|c|c|c|c|c|c|}
\hline Variable & Obs & Mean & Std.Dev. & Min & Max \\
\hline Log of FDI & 2306 & 5.09 & 2.58 & -4.71 & 11.57 \\
\hline Log of FDI(transformed) & 2306 & 5.14 & 2.46 & 0.00 & 11.57 \\
\hline Log of GDP in source country & 5100 & 13.10 & 1.20 & 10.93 & 16.53 \\
\hline Log of GDP in host country & 5100 & 10.10 & 1.21 & 7.57 & 13.18 \\
\hline Log of difference in GDP per capita & 5100 & 9.91 & 0.78 & 3.23 & 11.42 \\
\hline Log of distance & 5100 & 7.39 & 0.70 & 5.48 & 9.11 \\
\hline Language, border and cultural similarities & 5100 & 0.02 & 0.14 & 0.00 & 1.00 \\
\hline WTO membership & 5100 & 0.68 & 0.47 & 0.00 & 1.00 \\
\hline Bilateral FDI agreement & 5100 & 0.80 & 0.40 & 0.00 & 1.00 \\
\hline Log of bilateral exports & 4413 & 4.42 & 2.62 & -12.43 & 12.26 \\
\hline Log of schooling & 5080 & 3.66 & 0.45 & 2.33 & 4.50 \\
\hline Log of transition progress & 4760 & 3.31 & 0.23 & 2.30 & 3.57 \\
\hline Log of Consumer Price Index & 5100 & 1.33 & 0.30 & 0.69 & 1.90 \\
\hline Log of control of corruption & 5100 & 3.90 & 0.49 & 1.92 & 4.46 \\
\hline Log of regulatory quality & 5100 & 4.12 & 0.37 & 2.87 & 4.52 \\
\hline Log of government effectiveness & 5100 & 3.97 & 0.51 & 1.92 & 4.44 \\
\hline Log of political risk & 5100 & 3.92 & 0.53 & 1.35 & 4.49 \\
\hline Log of voice and accountability & 5100 & 4.12 & 0.33 & 2.49 & 4.49 \\
\hline Log of rule of law & 5100 & 3.91 & 0.49 & 2.21 & 4.46 \\
\hline Log of Consumer Price Index*see dummy & 5100 & 0.35 & 0.51 & 0.00 & 1.48 \\
\hline Log of transition progress*see dummy & 4760 & 1.12 & 1.51 & 0.00 & 3.47 \\
\hline Log of control of corruption*see dummy & 5100 & 1.15 & 1.66 & 0.00 & 4.15 \\
\hline Log of regulatory quality*see dummy & 5100 & 1.24 & 1.76 & 0.00 & 4.25 \\
\hline Log of government effectiveness* see dummy & 5100 & 1.16 & 1.67 & 0.00 & 4.27 \\
\hline Log of political risk*see dummy & 5100 & 1.11 & 1.60 & 0.00 & 4.22 \\
\hline Log of voice and accountability*see dummy & 5100 & 1.26 & 1.79 & 0.00 & 4.23 \\
\hline Log of rule of law*see dummy & 5100 & 1.24 & 1.76 & 0.00 & 4.25 \\
\hline SEE-dummy & 5100 & 0.33 & 0.47 & 0.00 & 1 \\
\hline
\end{tabular}


APPENDIX 3: Correlation matrix between variables employed in the model

\begin{tabular}{|c|c|c|c|c|c|c|c|c|c|c|c|c|c|c|}
\hline & LFDI & LGDP_S & LGDP_H & LDIFG Ca & LDISTW & SMCTRY & WTO & BFDIA & LBEX_1 & LSCH & LTP & LCPI & LCC_pr & LRQ_pr \\
\hline LFDI & 1.0 & & & & & & & & & & & & & \\
\hline LGDP_S & 0.2 & 1.0 & & & & & & & & & & & & \\
\hline LGDP_H & 0.5 & 0.0 & 1.0 & & & & & & & & & & & \\
\hline LDIFGDPC & 0.3 & 0.2 & 0.0 & 1.0 & & & & & & & & & & \\
\hline LDISTW & -0.3 & 0.4 & 0.1 & 0.0 & 1.0 & & & & & & & & & \\
\hline SMCTRY & 0.2 & -0.2 & 0.0 & 0.0 & -0.4 & 1.0 & & & & & & & & \\
\hline WTO & 0.2 & 0.0 & 0.3 & -0.1 & 0.1 & -0.1 & 1.0 & & & & & & & \\
\hline BFDIA & 0.1 & 0.0 & 0.2 & 0.1 & 0.1 & -0.1 & 0.2 & 1.0 & & & & & & \\
\hline LBEX_1 & 0.7 & 0.3 & 0.6 & 0.0 & -0.3 & 0.1 & 0.2 & 0.0 & 1.0 & & & & & \\
\hline LSCH & 0.2 & 0.0 & 0.3 & 0.0 & 0.0 & -0.1 & 0.4 & 0.2 & 0.3 & 1.0 & & & & \\
\hline LTP & 0.4 & 0.0 & 0.5 & 0.0 & 0.0 & 0.0 & 0.6 & 0.4 & 0.4 & 0.6 & 1.0 & & & \\
\hline LCPI & 0.1 & 0.0 & 0.2 & -0.1 & -0.1 & 0.0 & 0.3 & 0.1 & 0.3 & 0.6 & 0.7 & 1.0 & & \\
\hline LCC_pr & 0.2 & -0.1 & 0.3 & -0.1 & 0.0 & 0.0 & 0.4 & 0.1 & 0.4 & 0.6 & 0.7 & 0.9 & 1.0 & \\
\hline LRQ_pr & 0.2 & 0.0 & 0.2 & -0.1 & 0.0 & 0.0 & 0.5 & 0.1 & 0.3 & 0.6 & 0.8 & 0.8 & 0.8 & 1.0 \\
\hline LGOV_pr & 0.2 & -0.1 & 0.2 & -0.1 & -0.1 & 0.1 & 0.4 & 0.1 & 0.3 & 0.5 & 0.8 & 0.8 & 0.8 & 0.8 \\
\hline LPS_pr & 0.2 & -0.1 & 0.3 & -0.1 & 0.0 & 0.1 & 0.5 & 0.0 & 0.4 & 0.4 & 0.7 & 0.7 & 0.8 & 0.8 \\
\hline LVA_pr & 0.2 & -0.1 & 0.3 & -0.1 & 0.0 & 0.0 & 0.4 & 0.1 & 0.4 & 0.5 & 0.7 & 0.8 & 0.9 & 0.9 \\
\hline LRL_pr & 0.2 & -0.1 & 0.3 & -0.1 & 0.0 & 0.0 & 0.4 & 0.1 & 0.4 & 0.6 & 0.7 & 0.8 & 0.9 & 0.9 \\
\hline LCPIS & -0.2 & 0.1 & -0.3 & 0.1 & -0.1 & 0.1 & -0.4 & 0.0 & -0.3 & -0.4 & -0.5 & -0.5 & -0.5 & -0.6 \\
\hline LTPS & -0.2 & 0.1 & -0.3 & 0.1 & -0.1 & 0.1 & -0.5 & -0.1 & -0.4 & -0.4 & -0.5 & -0.5 & -0.6 & -0.7 \\
\hline LCC_prs & -0.2 & 0.1 & -0.3 & 0.1 & -0.1 & 0.1 & -0.5 & 0.0 & -0.4 & -0.4 & -0.5 & -0.5 & -0.5 & -0.7 \\
\hline LRQ_prs & -0.2 & 0.1 & -0.3 & 0.1 & -0.1 & 0.1 & -0.4 & -0.1 & -0.4 & -0.4 & -0.5 & -0.5 & -0.6 & -0.7 \\
\hline LGOV_prs & -0.2 & 0.1 & -0.3 & 0.1 & -0.1 & 0.1 & -0.4 & -0.1 & -0.4 & -0.4 & -0.5 & -0.5 & -0.5 & -0.7 \\
\hline LPS_prs & -0.2 & 0.1 & -0.3 & 0.1 & -0.1 & 0.1 & -0.4 & -0.1 & -0.4 & -0.4 & -0.5 & -0.5 & -0.5 & -0.7 \\
\hline LVA_prs & -0.2 & 0.1 & -0.3 & 0.1 & -0.1 & 0.1 & -0.5 & -0.1 & -0.4 & -0.4 & -0.5 & -0.5 & -0.6 & -0.7 \\
\hline LRL_prs & -0.2 & 0.1 & -0.3 & 0.1 & -0.1 & 0.1 & -0.4 & -0.1 & -0.4 & -0.4 & -0.5 & -0.5 & -0.6 & -0.7 \\
\hline SEEd & -0.2 & 0.1 & -0.3 & 0.1 & -0.1 & 0.1 & -0.5 & -0.1 & -0.4 & -0.4 & -0.5 & -0.5 & -0.6 & -0.7 \\
\hline
\end{tabular}

LGOV_LPS_pr LVA_pr LRL_pr LCPIS LTPS LCC_prs LRQ_prs LGOV_prs LPS_prs LVA_prs LRL_prs SD

LGOV_pr $\quad 1.0$

LPS_pr $\quad 0.8 \quad 1.0$

LVA_pr $\quad 0.8 \quad 0.8 \quad 1.0$

$\begin{array}{lllll}\text { LRL_pr } & 0.8 & 0.8 & 0.9 & 1.0\end{array}$

LCPIS $\quad-0.4 \quad-0.6 \quad-0.7 \quad-0.6 \quad 1.0$

$\begin{array}{lllllll}\text { LTPS } & -0.5 & -0.7 & -0.7 & -0.6 & 1.0 & 1.0\end{array}$

$\begin{array}{llllllll}\text { LCC_prs } & -0.5 & -0.6 & -0.7 & -0.6 & 1.0 & 1.0 & 1.0\end{array}$

$\begin{array}{lllllllll}\text { LRQ_prs } & -0.5 & -0.7 & -0.7 & -0.6 & 1.0 & 1.0 & 1.0 & 1.0\end{array}$

$\begin{array}{llllllllll}\text { LGOV_p } & -0.4 & -0.6 & -0.7 & -0.6 & 1.0 & 1.0 & 1.0 & 1.0 & 1.0\end{array}$

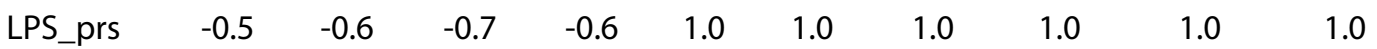

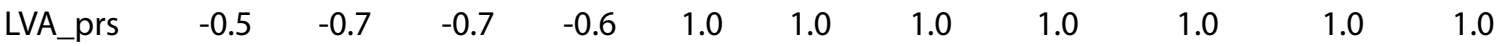

$\begin{array}{llllllllllll}\text { LRL_prs } & -0.5 & -0.7 & -0.7 & -0.6 & 1.0 & 1.0 & 1.0 & 1.0 & 1.0 & 1.0 & 1.0\end{array}$

$\begin{array}{lllllllllllll}\text { SEEd } & -0.5 & -0.7 & -0.7 & -0.7 & 1.0 & 1.0 & 1.0 & 1.0 & 1.0 & 1.0 & 1.0 & 1.0\end{array}$

